\title{
Introduction
}

value of the painting, now in the Palais Liechtenstein, Vienna, seems to be a later modification.

2 Sumowski 1983, vol. 4, 2364; Fanti 1767, 502. Baumstark 1987, 32: '(...) das genialisch rembrandteske Idealbildnis eines gerüsteten Kriegers von Christof Paudiss, dem aus Norddeutschland stammenden Mitglied der Rembrandt-Werkstatt'. probably also the model for the Man with the Golden Helmet in Berlin, which was therefore attributed to Karel van der Pluym. See Adams 1984, 427-441.

Horst Gerson mentioned the 'Rembrandtianer' (Gerson 1983, 340). He also used another term: 'In Germany the fashion of so-called Rembrandtisation reached its peak in the mid-eighteenth century. One of the leading Rembrandtists was Januarius Zick'. See Heiland \& Lüdecke 196o, 11-12. In this case, however, 'Rembrandtisation' is understood as the reception of the artist, as it took place long after his death. The term 'Rembrandtist' was correspondingly used in this context. See the recent exhibition catalogue of Rembrandt's late works (Cat. Amsterdam \& London 2015). Cf. North 2001; North 2006, 86-98. See the catalogues of the following exhibitions: Cat. London 1953; Cat. Leiden 1956; Cat. London 1969; Cat. Amsterdam 1983; Cat. Amsterdam etc. 1991; Cat. Tokyo etc. 1992; Cat. The Hague 1992; Cat. New York 1995; Cat. Melbourne \& Canberra 1997; Cat. Hamburg 2000; Dominicus-van Soest 2009, 8-11; Cat. New York 2011. The recent exhibition catalogue Rembrandt's Late Pupils: Studying under a Genius (2015) argues in a similar vein, deviating slightly in some aspects. Dickey adopted a more dynamic approach in 2016, 169-201. See also Dickey 2017 and Cat. Berlin 2018.
Sumowski 1989, vol. 5.; Sumowski 1994. Cf. van Dyke 1923; Laurie 1932; Białostocki 1956, 349-369; Cavalli-Björkman 1993.

Cat. Melbourne \& Canberra 1997, 212. Sumowski 1989, vol. 1, 82: 'In letzter Zeit ist gegen den Begriff Rembrandt-Schule opponiert worden. Das Wort Schule, so heist es, könne strenggenommen nur auf eine Künstlergruppe mit einheitlichem, von ihrem Lehrer bestimmten Stil angewandt werden, und Einheitlichkeit herrsche hier nicht. Der Logik nach ist dieser Einwand berechtigt. Denn die Mehrzahl der Meister, die bei Rembrandt gelernt haben, richtet sich nur zeitweilig nach seinem Vorbild, gelangt im Verlauf des Schaffens zu Formen, die nichts mehr von ihrer Schulung verraten. Auch wird gelegentlich simultan rembrandtesk und individuell gearbeitet'.

Van de Wetering 2010, 130: 'The problem with Slive and Emmens' account is that it places Rembrandt in a void as far as any structured way of thinking about art is concerned - in Emmens' words - the "Tuscan Roman negative". But what is needed is a 'positive understanding of Rembrandt's way of thinking, an understanding of how and why his ideas deviated so radically from the norms of Classicism'. This observation is paramount for the present research. See more recently Van de Wetering 2016.

Weststeijn 2008.

The relevant passage in De Lairesse 1740, vol. 1, 325 , reads: '(...) niettegenstaande dat men 'er vond, en noch vind, welke vast stellen dat het in zyn [Rembrandts] vermogen was alles 't welk de konst en 't penceel kon uitvoeren, hebbende hy alle de beroemdsten van zynen tyd tot heden toe overtroffen'. Cf. Slive 1988, 165. On page 199 Slive asks 'how large was the inarticulate audience which had an appreciation of Rembrandt's work?' The present study seeks to answer this question.

See for example the work of Andy Clark \& David Chalmers (1998); Shaun Gallagher (2006); John Michael Krois (2011); Alva Noë; Varela et al. 
(1991) among others, which is discussed in the following chapters. It would be better to speak of 'philosophies of embodiment' instead of a single 'philosophy of embodiment', as this encompasses several currents (enactive, embedded, extended). Cf. Fingerhut et al. 2013 .

One of the exceptions is Roodenburg 2004 (who tellingly adopts a primarily cultural-historical take on the issue). Although the title of a recent article on Rembrandt contains the word embodiment, it does not deal sufficiently with this respective theory even if it is an intriguing study for other reasons (Koos 2017).

Roger de Piles, therefore, speaks of couleur naturelle and couleur artificielle. Cf. Imdahl: 2003, 27. Jacqueline Lichtenstein, too, emphasizes this: 'Roger de Piles distinguishes colour as matter, "which makes objects visible", from coloris as form, the "essential part of painting", by which the painter imitates the appearance of colours and which includes the use of chiaroscuro'. Lichtenstein 1993, 153.

Hoecker 1916, 288: 'Verw in der natuer werct wonderbaer crachten'.

Hoecker 1916, 288: 'Waer van oock Exempelen zijn te speuren/Van ontfanghende Vrouwen/ wiens gedachten Yet so imaginerend/ oock voort brachten/ Sulcke vrucht/ 't zy swart/ oft ander coleuren Maer dit weten wy/ en sien het ghebeuren/ Dat de Kinderlijven vlecken ghenieten/ Van 't ghene / daer de Moeders in verschieten. Ghelijck wanneer sy somtijts onverhoedich/In bloedstortinghen/ schrickelijck verschrommen/ Brengen haer kinders litteeckenen bloedich/ Oft ander verwe vlecken overvloedich/ (...) Dus blijct der verwen cracht/ (...)'. Unless otherwise specified, the translations of quotes are by the translator of the book. Roodenburg 1988, 701-716.

Slive 1988, 206. 'Dat braef penceel en hoeft na niemands lof te vragen; 't Is door sich self vermaard $(. .$.$) '.$ For the term, see recently: Suthor 2014.

Cat. Haarlem 2013.

Schnackenburg 2001, 99.

For the differentiation between seeing in and seeing as, see: Wollheim 1980, 205-226. The notion of ikonische Differenz draws on this distinction. For some first impulses, see Boehm 1994. Werner Busch's study Das unklassische Bild (2011) opens new perspectives from the early modern to the

beginning of the modern period, and answers questions crucial to the present study. example, Willem Goeree (1670) used the word handeling and 'manner' synonymously in his introduction to the art of drawing, 98: 'Handelende van de verscheide manieren en handeling die men in het Teikenen houden moet' and 99: '(...) wat manier of handeling ons best behaagt (...) deselve manier en handeling van hun Principaal volgen'. Cf. the term handeling in: WNT 1900, vol. 5. The dictionary lists the various meanings of the term too: 'a. Het aanvatten of aangrijpen in de hand nehmen, betasten (touching and handling, which can likewise be intuitive - op het gevoel - in terms of the thinking hand, see Chapter II), col. 1915; b. the skill in handling instruments (col. 1916); c. the modality, manner, or form of a thing or an artist (De wyze, op welke de pypen gevormt worden, dat met eene verbaazende vaardigheid en handeling geschied), which in French is called 'le faire, la manière, la méthode d'un peintre' and otherwise behandelung (treatment), (col. 1917); d. 'het bedrijven, doen, verrichten' (doing); and (col. 1920) e. the narrative action or plot of a play, which can be translated as the subject or story told in a picture'. 
Karel van Mander 1916, 266: 'Met de verwe handelen sonder schricken'. Franits 1995, no. 71, 415. This is postulated by James Elkins in the broader context of the Baroque: '(...) line and colour depend on one another in ways that were not always acknowledged'. Cf. Elkins 1995, 846. Cf. the website of RKD (Rijksbureau voor Kunsthistorische Documentatie): http://www. rkd.nl/rkddb/(S(mxnljx2ok5lxsuojzh3ybmid))/ brief.aspx [5 Nov. 2013]. No reference is made to a study that investigates a productive relationship between theory and practice, or to how theory is a product of handeling. Nicolaas van der Monde's publication is a practical manual that explains the basics of painting for amateurs and art enthusiasts in the nineteenth century. Cf. Van de Wetering 2010. Ketelsen 2000, 15-17. See a similar argumentation in Ketelsen 2006, 8-26. See also Miedema 2017, 210-220.

7 'Das man gleich anfangs einer zierlichen saubern Zeichen-Manir und Handlung/ [author's emphasis] es sey gleich mit der Feder/Kreiden oder Pensel/ zu dieser edlen Zeichenkunst/ sich befleisse und gewohne', Sandrart 1679, III, 12:http://ta.sandrart.net/de/ text/1001 [6 Feb. 2014]. Van Hoogstraten 1678, 233. Van Mander says in much the same way that 'en wat een gheestighe fraey handelinghe en wijze van doen', cited from WNT, vol. 5, 1917. From Goeree's point of view, artists acquire their characteristic handeling by diligently copying the famous masters. See Tummers 2011, 116. Houbraken 1753, vol. 3, 206.

10 Tummers 2008, 39.

$11 \quad$ Emmens 1979, 121.

12 Van Hoogstraten 1678, 307: '(...) dat men 't geen voorkomt, rul en wakker aensmeere, en 't geen weg zal wijken, hoe verder en verder netter en zuiverder handele'. Van Hoogstraten devotes an entire section to handeling in book 7 (233-242). See Chapter v, second part.

14 Löhr 2008, 154. Such connotations are found in the Netherlands too and are examined in Chapter II. maneggio Sohm mentions an Italian description of handeling in the sense of how an instrument was wielded: 'il modo di (...) portar la pena'. 1998, 277-298; Rosen 2013 and Beyer \& Gamboni 2014.

Vossius translates the word actio as handeling. Weststeijn 2008, 234; Weststeijn 2013a, 183.

Cited in Weststeijn 2008, 171: 'De Poësie is een suster, ja een lidt, van mijn Godinne Pictura, dieshalven heb ik wel veranderingh in de handelingh [author's italics], maer niet in 't verstant begaan, overwegende, besinnende, en beschouwende de affecten en passien der menschen'.

Weyerman 1729, vol. 1, 27: 'Wy noemen manier, een zekere handeling des Schilders, niet alleen van zyn Hand maar van zyn Gemoed'

1 Weyerman 1729, vol. 1, 27: 'Het woord Manier betekent in een Schilder het zelve, dat het woord Stijl betekent in een Autheur; want een schilder is bekent by zyn Manier, gelyk als een Autheur is by zyn Stijl, of een Koopmans Hand is by zyn Schrift'. (For a painter, the word manner means much the same as the word style does for a writer; the painter is famous for his manner, the writer for his style, or the merchant is known by his signature.)

22 Dethlefs 2010, 218. The sense in which the art theoretician Christian Ludwig von Hagedorn speaks in the eighteenth century of Handlung is the specific way in which individual artists wielded their brushes and other tools and how they employed them to give each of their artworks a specific character or manner. The context here emphasizes the meaning of handling that was observed above in Sandrart. Poussin correspondingly adapted his manner to correlate with the subject matter: 'I painted the picture in this way (manière), as you see before you, because the subject is per se of a gentle nature, in contrast to that of Mr. de la Vrillière's painting, which is of a more serious nature. This is the sensible thing to do if you take into consideration that the subject is heroic'. For the present attempt, the term handeling seems more appropriate than the notion of modus, which found its specific legitimacy in Poussin's art and was based on varietas (variety). Białostocki 1966a, 9-35. Cf. Bredekamp 2011, 277-284. Handeling is understood as manner, often with an emphasis on naturalness in regard to the materiality of things along with a caveat against manipulating 
the paint in a way that goes beyond the simple observation of nature (See Chapter III, 110-112 and 134-136). Handeling itself, thus, evolved into a mannered manner as was lamented not only by contemporary critics of mannerism, but later ones as well. Censoring 'degeneracy in art' can be seen in this way, too, as its protagonists argued along the same lines as in early modern academic art criticism. See Bredekamp 2000, 109-129; Aurenhammer 2016, 14-23.

24 Karel van Mander 1916, 212.

25 Van Hoogstraten 1678, 30 and 234-235. Translation from Van de Wetering 2010, 122-123: '(...) [w]ant men moet zijn handeling nae den aert der dingen somtijts veranderen. De derde Les is, nae den aert van 't leven, Een yder ding zijn eygenschap te geven, In 't handelen: men wen zich geen manier, Als die zich strekt tot aller dingen zwier. (...) Bekreun u weynich met een handeling of manier van schilderen te leeren, maer wel, om gestadich in de opmerking vaster te worden, en de deelen der konst wel te onderscheyden, en met wakkerheyt nae te volgen. Zoo zal de hand en 't penseel het oog onderdanich worden, om manierlijk de verscheydenheyt der dingen, elk nae zijn aert, op 't zwierichst uit te beelden. (...) Geen eygen handeling te betrachten, maer alleen de natuerlijkheyt [Margin of the book, Y.H.]. (...) Want daer behoort een andere lossicheit van handeling tot het luchtige hair (...) en wederom, een anderen aert van 't pinseel te roeren in 't schoone naekt, en het blinkende marber'. Gerard de Lairesse presents similar theories in his Schilderboek (127-137). See Dethlefs 2009, 217; De Vries 2011, 30 and $67-69$.

'Man soll sich an keine Manier/ Gewohnheit oder angenommenen Gebrauch binden/ sondern wie die Natur immer alles verändert und anderst gebieret/ also sollen wir immerzu in allem uns verändern und von dem guten zum bässern wenden'. Sandrart 1675, I, 102 under: http://ta.sandrart.net/edition/text/ view/193\#tapagehead [14 Jan. 2014]. See Chapter II (section three).

28 Cited from Sluijter 2006, 209. Cf. De Ville 1628.

29 Sluijter 2006, no. 88, 392. Cited from his translation, 210: '(...) de handelingh weynich acht ten aensien vande teecken konst, daer nochtans hedens-daechs meest naer ghesien werdt'.
Sluijter 2006, no. 89, 392. Cited from his translation, 210: '(...) anders niet en doen dan vlack naer het leven te schilderen en die verwen soo handelen dat daer niet boven te komen is aengaende de handelinghe'.

$31 \quad$ Sluijter 2006, no. 90, 392: '(...) lief-hebbers die voor een Tronij 2.3.4. hondert gulden, ende meerder betalen, het welcke nochtans maer het achtste ghedeelte van het lichaem is (...) de Luyden alleen op handelinghe sien (...) dan voor het gene dat met goede simmetrije gemaeckt is'. See Tummers 2011, 127.

As Horst Bredekamp emphasized, the reference to mannerism becomes apparent again here: 'Als historiographischer Begriff der Kunstgeschichte existierte der Manierismus aber noch nicht. Er entstand erst als Produkt einer uber Jahrhunderte wahrenden Kritik des "zu viel an Handfertigkeit”.' Bredekamp 200, 111.

33 Tummers 2011, 128.

34 Tummers 2011, 128.

35 Puttfarken 1985, 49.

36 Cited from Gombrich 2004, 150; Stückelberger 2006, 113 .

37 Tummers 2011, 161. On Goltzius and the novelty of his handeling at the time, which involved diversity, see: Büttner 2011, 87-109.

38 Van Hoogstraten 1678, 12. Cited in Van de Wetering 2010, 9: 'Dat hy niet alleen het doode lichaem der konst beooge, dat is trant te volgen, en te doen als andre, maer dat hy op de ziele der konst als verslingert is: dat is, de natuur in hare eigenschappen te onderzoeken. Hy is nijdich dat een ander iets, hem onbekent, weet, hy schaemt hem van iemant iets indrukkender wijze te leeren, en zoekt alles door eygen arbeit uit te vinden' This statement answers a question put by Carel Fabritius, which he asked at a time when both painters were working in Rembrandt's studio in the 1640 s. True spirit, thus, lies in probing all facets of abundance. This expresses an artistic mindset the Rembrandtists learned from their master.

39 Van Hoogstraten $1678,175^{-176}$. Cited in Van de Wetering 2010, 59: 'Dezen zal 't lusten, wat stof hy ook voorheeft, de zelve deur aerdige deelen wonder behaeglijk te doen schijnen, als of hy meer vermaeks had in 't vertoonen van een soorte der medewerkende dingen, als in 't gros van de zaek; 't zy in geestige bewegingen, 
tronien, toetakelingen of teujeringen. (...) Maer de derde acht alleen een bloote en onbedwonge vertooning en bralt quansuys op ' $t$ ware groots, volgt de Roomsche zwier van Rafael en Angelo, en houd staende, dat der dingen defticheit door 't uitbeelden der geringen lijdingen gekreukt wort: dat de Schilderkonst in top is, daerze alleen op heldachtige deugden acht geeft: dat het bedwang der lichten en schaduwen een brosse kruk is: en onrecht datmen, om het eene te verschoonen, het andere verduistere'. See Chapter II, 102-104.

Van Hoogstraten 1678, 176.

For an elaboration of this point, see:

Hadjinicolaou 2016d; Houbraken 1753, vol. 2, 343-344.

Weyerman 1769, vol. 4, 24.

Houbraken 1753, vol. 3, (206) mentions how De Gelder went to Amsterdam to study with Rembrandt: '(...) naar Amsterdam vertrok om Rembrandts wyze van schilderen te leeren, 't geen hem zoodanig toeviel en gelukte, dat ik tot zynen roem zeggen moet dat geen van alle hem zoo na gekomen is in die wyze van schilderen [handeling Y.H.]'

Weyerman 1769, vol. 4, 24. 'Echter stremde die keurlyke behandeling geenzins de vrymoedige toetsen van zyn Konstpenseel, zo op de verheevenste lichten, als in de uiterste diepsels, welke behandeling het oog op eene aangenaamer wyze kittelt, als de al te stoute toetsen van Rembrant van Ryn, Arnould de Gelder, en diergelyke ruuwe Konstschilders'. Only just before this Weyerman asserted that (22): 'Het koloriet van Karel de Moor is verwonderlyk (...) [is] minder kragtig [kraftig] geweest als Titiaan (...) en als Rembrant van Ryn'.

See Chapter III, 126-128.

Van Gool 1750-1751, vol. 1, 296: 'vlezige en vleiënde wyze van schilderen.'

Houbraken 1753, vol. 2, 20-21: 'Maar alzoo te dier tyd de handeling van Rembrant in 't algemeen geprezen wierd, zoo dat alles op die leest moest geschoeit wezen, zou het de Waereld behagen; vond hy [Govert Flinck] zig geraden een jaar bij Rembrandt te gaan leeren; ten einde hy zig die behandeling der verwen en wyze van schilderen gewende, welke hy in dien korten tyd zoodanig heeft weten na te bootsen dat verscheiden van zyne strukken voor egte penceelwerken van Rembrant wierden aangezien en verkogt'.
Houbraken 1753, vol. 3, 206: 'De Konst van Rembrant had als wat nieuws in haar tyd een algemeene goedkeuring; zoo dat de konstoeffenaren (wilden zy hunne werken gangbaar doen zyn) genootzaakt waren zig aan die wyze van schilderen te gewennen; al hadden zy zelf eene veel prysselyker behandelinge. Waarom ook Govert Flink (gelyk wy in zyne levensbeschryving hebben aangemerkt) en anderen meer, zig tot de school van Rembrandt begaven'.

49 Houbraken mentions two other artists as pupils of Rembrandt who painted in the manner of their master thoughout their lives: Franz Wulfhagen (Houbraken 1753, vol. 1, 273: 'Frans Wulfhagen geboren te Bremen, heeft de behandeling van zynen meester met veel roem weten na te bootsen, en zig ook daar aan tot het einde van zyn leven gehouden') and Gerbrand van den Eeckhout (Houbraken, 1753, vol. 2, 100: 'Hy was een leerling van Rembrant van Ryn, en bleef tot het einde van zyn leven by de zelve wyze van schilderen, welke hy van zyn meester geleerd had'). In contrast to Wulfhagen, who does not seem Rembrandtesque to us today because he painted in the fine' manner, Van den Eeckhout, who Houbraken praised as Rembrandt's best pupil, proves to be a more complicated case: 'A versatile artist, Eeckhout not only treated different kinds of subject matter (...) but also, throughout his career, worked in several styles simultaneously'. Cf. Dixon/ten-Doesschate Chu 1989, 610 . Cf. Hinz 1974, 139-218.

51 Loughman 1998, 220. The picture is dated around 1700 . That the particular painting is not a self-portrait may be proven by the fact that there is a double marriage portrait of the same sitter (see the plate in Moltke 1994, nos. 100 and 101). De Gelder was not married. Van Hoogstraten 1678, 235. Cf. Van de Wetering 2010, 117: 'Nu zoo moetmen ookzijn handeling voornamentlijk veranderen na de plaets, daer het werk te staen heeft: want het zal u wel dapper berouwen, wanneerge in 't schilderen van een stuk, dat hoog uit de hand zal hangen, en van verre moet gezien worden, veel tijts met kleinicheden verquist hebt. Neem dan vry borstels, die een hand vullen, en laet yder streek 'er een zijn, en de verwen op veel plaetsen byna onvermengt leggen; want de hoogte en de dikheit der lucht 
zal veel dingen smeltende vertoonen, die by zich zelven steekende zijn'. Hadjinicolaou 2013, 243.

54 Van Hoogstraten 1678, 234-235. Van de Wetering 2010, 123: 'Zoo zal de hand en 't penseel het oog onderdanich worden, om manierlijk de verscheydenheyt der dingen, elk nae zijn aert, op 't zwierichst uit te beelden'.

55 Van Hoogstraten 1678, 233. Van de Wetering 2010, 123: '(...) datmen zich tot een wakkere pinseelstreek gewoon maeken, die de plaetsen, die van andere iets verschillen, dapperlijk aenwijze, gevende de teykening zijn behoorlijke toedrukkingen, en de koloreeringen, daer 't lijden kan, een speelende zwaddering (...)'.

$5^{6} \quad$ Van de Wetering 2010, 123. Similar observations of the diversity of Van Hoogstraten's vocabulary in regard to form can be found not only in the publication on the history of Dordrecht (Frijhoff et al. 1998, 390), but also in the most recent collected volume on the artist which addresses his art as a central phenomenon (Weststeijn 2013c, 10).

57 David de Witt laconically commented on the differentiated nature of the artist's manner of painting by saying that 'De Gelder may have adhered to Rembrandt in some aspects, but not in all things. He had a different sensibility, and varied his approach from painting to painting, but this escaped Houbraken'. De Witt 2003, 86.

$5^{8}$ Van Dyke 1923, 89. Van Dyke also made the remarkable observation that reproductions are highly insufficient in demonstrating a special handeling (90): 'De Gelder is to be traced less by his types than by his colour and his handling, of which the photograph gives little or no hint'. Valeska von Rosen has confirmed that this principle was found even earlier when she talks of Titian's formal diversity, that is, of the great model to which all the Rembrandtists aspired. Von Rosen 2001, 334. Loughman 1993, 22. For this argument in greater depth depth, see: Hadjinicolaou 2016a.

60 Loughman 1993, 23-27.

61 Loughman 1993, 21.

62 Loughman 1993, 21 and 26.

63 Loughman 1992, 36.

64 Chong 1994, 10.

65 Huizinga (Huizinga 2007 [1941]) championed the idea of a national Dutch school. In response to this, Haak argued for the existence of important local schools (Haak 1984), and this notion continues on until today (Franits 2008). Eric Jan Sluijter and Marten Jan Bok see the resonance of artistic personages like Rembrandt as the reason why local schools and their limitations did not play a decisive role. This does not mean that local art schools had no characteristics that were linked to the local demands prevalent in a city, such as the fijnschilderkunst in Leiden. Cf. Cat. Dordrecht 1992; Loughman 1993, 31.

Chong/Wieseman 1992, 13 and 20; Loughman 1993, 32; Loughman 1998, 43 .

67 Houbraken 1753, vol. 3, 206.

68 Loughman 1998, 43.

69 Loughman 1991, 532-537; Loughman 1993, 298-305.

$70 \quad$ Loughman 1993, 298-305.

$71 \quad$ Pastoor 1994, 6.

72 Wurzbach 1970, 370. For this reason, Houbraken doubted if De Gelder would finish his series of the Passion.

73 Weyerman 1729, vol. 3, 44: 'Arent de Gelder, die een Schilder in de ziel was en op schilderachtige manier leefde'.

74 Brusati 1995, XXII.

75 Cat. New York 1995, vol. 2, 31-32.

76 Loughman 1998, no. 9, 38: 'Von Moltke lists over 300 references to paintings by De Gelder, mostly taken from auction catalogues, which cannot, however, be identified with any of the surviving works'.

77 Cf. Von Moltke 1994, 119-168.

78 Schoon 1998, 16; Loughman 1998, 42. In regard to the goldsmith Anton de Vos being accountable for his actions, it is clear that not only Moelaert, but also De Gelder together with other friends were his guarantors.

79 Pastoor 1994, 6-7. See Jacob Moelaert's inventory in the Dordrecht archives. GAD (Gemeente Archief Dordrecht), onA (Oud Notarieel Archief, Dordrecht) 20 854, fol. 261-313, 4 Aug. 1727. Moelaert owned works - to mention just a few - by Callot, Van Hoogstraten, Houbraken, De Lairesse, Maes, Van Mander, Mignard, Raphael, Rembrandt, Rigaud, and Titian. Cf. Czech 2002, 119-121.

8o Golahny 2003, 216. Cf. the inventory of Arent de Gelder, in: Von Moltke 1994, 203: 'Boven op de middelkamer: bibliotheecq(u)e, bestaande in twee kasten en een klijndere, met boeken'.

81 Cat. Dordrecht \& Cologne 1998, 170. 
Catalogue Dordrecht \& Cologne 1998, 170. Catalogue Dordrecht \& Cologne 1998, 170. Catalogue Dordrecht \& Cologne 1998, 202. De Vrij 1994, 113-124; Loughman \& Montias 2000, 131.

Loughman 1998, 40; Loughman \& Montias 2000, 131.

Catalogue Dordrecht \& Cologne 1998, 203.

Zell 2002, 181.

Van de Wetering 1999, 8-37.

Zell 2002, 192.

This is investigated in depth in Chapter II.

Busch 2011b, 279.

Sluiter 1998a, 35-45.

Sumowski 1983, 911-912.

Pont 1958, 100. Pont compiled the only monograph on the artist.

Cf. Mai 2006; Cat. Dordrecht etc. 2006; Atkins 2012, no. 34, 270. Schmidt-Degener 1928, 41:

'The circle in which the late Rembrandt was received with enthusiasm was exceptionally small. It comprised those immediately connected with him, middle-class people who were not influential, such as De Decker, or exceptions such as his pupil Aert de Gelder'.

Houbraken 1753, vol. 1, 273: 'Onder de menigvuldige Leerlingen, die hy in de Konst heeft opgekweekt, worden ook deze volgende genoemt, die, om dat wy den tyd van hunnen geboorte niet weten, voeglykst staan agter hun meester geplaatst als PAUDIs, een Nedersakx (ook by Sandrart gemeld) die naderhand geschildert heeft by den Hertog Albert van Beijeren'.

He is presumed to have been in Rembrandt's workshop around 1645-1650. Cf. Cat.

Freising 2007, 11. See the text by Manuth 2007, 95 .

The catalogue is the very first monograph dedicated to the artist.

Dekiert 2008, 169 .

Seifertová 1977, 237. Seifertová speaks of a 'stubborn faith in Rembrandt'.

Cf. the two dated and signed pictures Old Man Wearing a Fur Cap, 1654, Dresden, and St. Jerome and the Angel, 1664, Freising.

Klessmann 2007, 92.

Benesch 1924, 161.

Benesch 1924, 161: 'Die monumentale Fülle der Gestalten Rembrandts ist in herbe Eckigkeit übergangen. Im Winkelrhythmus bewegen sie sich. Man beachte die schroffe Rechtwinkelverkurzung des über den Heiligen gebeugten Alten. Diese hat nichts mit der stillen Monumentalität der kubischen Formen des späten Rembrandt zu tun'.

106 Benesch 1924, 161: 'Etwas Schrilles, stoßhaft Eckiges, Verkrampftes liegt in den Bewegungen. Ebenso sprunghaft, auseinanderfallend, willkürlich sind die Proportionen und Größenrelationen. (...) Das Grauenhafte des Martyriums wird zum krankhaft Grässlichen gesteigert. Die Physiognomien sind in unheimliche, brutale Hysterie versetzt. Hysterisch ist an dieser Malerei alles: Komposition, Relationen, Einzelformen, Farben, Malweise. Die Farben sind dünn aufgetragen, die ganze krankhaft feine Zeichnung des Pinselstrichs, die in seltsamem Gegensatz zur Brutalitat der Darstellung steht, deutlich weisend'.

107 Peltzer 1937/8, 270: 'In grösseren Altarbildern bekommt zuweilen ein wilder, derber Realismus die Oberhand und zerstört die einheitliche Form und künstlerische Wirkung'. At the same time, Peltzer recognized the modernity of Paudiss' colour gradations, especially his greys (273): 'An exceptionally subtle feeling for colour allows him, the master of grey tones, to perceive and render even the most subtle gradations of hues in a way that only now, in modern times, can really be appreciated again'.

108 Liebmann 1972, 218. 'Paudiss' Malweise zeichnet sich durch einen sehr dünnen Farbauftrag aus; so dünn, das die Maserung des Holzes stellenweise durchscheint. An manchen Stellen jedoch ist der Farbauftrag pastos'.

109 Horst Gerson compared Paudiss, De Gelder, and Fabritius as follows: 'From Paudiss we have numerous studies of heads and genre-like portraits in the Rembrandtesque manner. In them he pursued a milder version of Rembrandt's chiaroscuro while imbuing it with more "beauty". His chiaroscuro was more grey and blurred, so that his paintings often look like the spiritless pieces by Aert de Gelder or Barent Fabritius'. Gerson 1983, 237.

110 Sumowski 1983, vol. 4, 2314. 'Zustand zwischen Materialität und Entkörperung, Masse und Durchscheinen, Schwere und Leichtigkeit, gleichzeitig Drastik und Verfremdung, Nähe und Distanz kann man sagen, welche eben aufgelöst werden'. 
111 Bauer-Empl 2007, 175. 'Im Gemälde der Tempelreinigung arbeitet Paudiss mit einem Facettenreichtum an transparenten und opaken Farbschichten, die der Gesamtwirkung des Bildes etwas ,Flackerndes' und damit große Lebendigkeit verleiht'.

Bauer-Empl 2007, 189: 'Compact areas of paint covering the surface of the canvas alongside loosely painted areas now contrast with one another even more strongly than they were originally meant to'.

113 Cf. the corresponding painting Supper at Emmaus as well as the Last Supper, which found decisive input in a print by Rubens: Cat. Munich 2008, 128 and 215-219. Paudiss, moreover, had access to another painting by Rubens, namely the Maria Victoria or The Apocalyptic Woman in Freising Cathedral and now in the Alte Pinakothek, Munich. Michael Thimann sees more generally the influence of Italian and Flemish painting besides that of Rembrandt and Lievens. See Thimann 2008, 515.

On this topic, see the following studies with a psychological bent: Klessmann 2007, 83-92; Steiner 2007, 110-132. Manuth 2007 (109) is much more careful and calls him, in the last sentence of his essay 'an exceptionally talented eccentric'. Leutner 2007a, 21-44 and Leutner 2007b, 45-82. Valentiner 1939, 322: '[Drost] changed style according to the artists by whom he was surrounded'.

11 Cf. Miller 1986, 75-82; Bikker 2005, 1.

118 Cf. Bikker 2002, 156: 'Simply absorbed the latest artistic trend in Venice. He was an innovator rather than imitator'.

119 Cf. Cat. Amsterdam 2006.

120 Bikker 2002, 150: 'Unlike Loth Drost died before he could build up a reputation in Venice and seventeenth-century Venetian writers on art took no notice of him'.

Houbraken laconically refers to Drost as a pupil of Rembrandt. Houbraken 1753, vol. 3, 61: 'Nu volgen DROST, VAN TERLEE, en POORTER. Deze schilderden Historien. Van den eersten die een Leerling van Rembrant was, heb ik een Johannes Predicatie gezien, die braaf geschildert en geteekent was'.

On this topic, see M. Loh's book on seventeenthcentury reception of sixteenth-century Venetian painting. Loh 2007.

Boschini mentions Loth several times in an affirmative way. Boschini 1966, p. 592 ('Un Carlo Loto de nation todesca (...)') and 594 ('Virtuoso xe 'l Loto $\left.(. . .)^{\prime}\right)$.

Bikker 2005, 14: 'Drost's technique can also vary dramatically from painting to painting. This observation has already been found to be a principle in Aert de Gelder's work. Bikker describes how this formal diversity unfolds within a painting, basing his observations on Rembrandt's portrait of Jan Six which displays both the fine and rough manner of painting.

Bikker 2005, 2.

Sumowski 1983 confirms this too, 1744: 'Leveck refrained from using extreme impasto'.

Sumowski ranks Leveck among Rembrandt's mediocre pupils.

Cf. Ekkart 1987, 11. The sitter was also Dordrecht's master of the mint.

A document verifies that Leveck was a pupil of Rembrandt. In 1653 he witnessed the appraisal of a painting, together with his tutor and another person, before an Amsterdam notary. See Sumowski 1983, 1744. Basically, the bibliography of Leveck comprises Sumowski's brief essay and Ekkart's article.

Houbraken 1753, vol. 2, 153: 'Hy had de Konst by Rembrant geleert, maar in zyne reize die handeling laten varen en zedert zig geheel tot het schilderen van pourtretten, vry wel zwemende naar die van de Baan, begeven. Hy hadde nog een stuk schildery van zyn eersten tyd in zyn huis, daar de handeling van Rembrant zoo wel in was waargenomen, dat men het voor een stuk van Rembrant zou hebben aangezien'.

Houbraken 1753, vol. 2, 153: 'Zyne Ouders hadden hem een fraai kapitaal naargelaten, maar na 't my toescheen (dewyl hy meer van gezelschap als van schilderen hield) was het met zyn reis in Vrankryk vry wat gesmolten'.

Houbraken 1753, vol. 2, 153 .

Houbraken 1753, vol. 2, 153-154.

Weyerman 1729, vol. 2, 229: '(...) onmaatig gebruyk van witte en van roode Wijnen, en in al te gestadiglijk vast te kleeven in de Delilas bouten van blanke en van bloozende Vrouwen'. 
Houbraken 1753, vol. 2, 21: 'Dog hy heeft die wyze van schilderen naderhand met veele moeite en arbeid weer afgewent; naardien de Waereld voor't overlyden van Rembrandt, de oogen al geopent wierden, op 't invoeren der Italiaansche penceelkonst, door ware Konstkenners, wanneer het helder schilderen weer op de baan kwam'.

136 Sumowski 1983, 1744.

137 '(...) dat Dordrechts vette kleigront wel goet is om kunstenaeren te queeken, doch niet om op den duur te voeden (...)'. van Gool 1750-1751, vol. 1, 299, cited from Loughman 1998, 37. Translation: Loughman 1993, 28: 'Dordrecht is a rich soil to cultivate painters, but not in the long run to nourish them'.

138 Cf. Krempel 2000.

139 For example, two portraits by Maes signed and dated ${ }_{1658}$ speak for this. One of them is now in Cologne. In his book Sumowski lists the painting now in possession of an unknown owner under no. 1393. Robinson is of the opinion that Maes' style changed radically from 1661 . Cf. Robinson 1993, 112-114.

Houbraken 1753, vol. 2, 274: '(...) verliet vroeg die wyze van schilderen [Rembrandts], te meer toen hy zig tot het schilderen van pourtretten begaf, en wel zag dat inzonderheid de jonge Juffrouwen meer behagen namen in het wit dan in 't bruin'. See Franits 1995, 395.

Lootsma 2007-8, 221-236; Franits 1995, 409. Franits (406) goes so far as to conflate painting manner and ideology, which is also targeted in the present study: '(...) the new French inspired sociocultural ideology is also expressed semiotically by such formal elements as light line and paint application'.

142 Chong 1994, 16; Schoon 1998, 14.

143 Cat. Cologne \& Dordrecht, 197; WagenaarBurgemeister 2009, 24-27.

144 Cat. Cologne \& Dordrecht 1998, 197.

145 Moltke 1994, 98; Cat. Cologne \& Dordrecht 1998, 197.

146 Sumowski 1983, 4006-4007; Cat. Cologne \& Dordrecht 1998, 197-198.

147 Sandrart mentions twice that he was one of Rembrandt's pupils. See Sandrart 1925, 206; Sandrart 1675, I, 240, under: http://ta.sandrart. net/de/text/458?item=auto15403\#auto15403 [17 Jan. 2014]: '(...) und dergleichen grose KunstLiebhaber sind damals sehr viel in Amsterdam gewesen/ wie mich [Joachim von Sandrart] dann auch der Kunst-berühmte Herr Johann Ulrich Mayr versichert/ daß er seinem Lehrmeister/ Herrn Renbrand/ für 14. Stuck von dieses Kunstlers saubersten Abdrucken (...) in einem offentlichen Ausruff 1400. Gulden bezahlen sehen'.

148 On the question of Tronje, see: Hirschfelder 2008; Gottwald 2011; Hirschfelder \& Krempel 2014.

149 The painting can also be viewed as a tronie. The etching of the lost original is by J. C. Schnell.

150 Sumowski 1983, 2175; Zeeb 2011, 189.

151 Sumowski 1983, 2182.

$15^{2}$ Cf. Kanzenbach 2007, 31-45. Cesare Ripa, in Iconologia (1593), speaks of 'con la destra mano sopra al capo di una statua di sasso', cited from Kanzenbach 2007, 85 .

153 Sandrart 1925, 206: 'Haben die uralte Griechische Mahlere ein unsterbliches Lob verdient, daß sie theils die Vogel, theils andere Thiere durch ihre gemahlte Werke betrogen, so hat unser Künstler wol verdienet, daß er auf den Thron höhster Ehren erhoben werde, weil er mit einer vor etlichen Jahren gemahlten Fensterrahm und daran hangendem Kammfuter, Scheeren, Federn und Briefen viele Anschauere verführet, daß sie die Sachen vor natürlich wahr gehalten'.

154 Sumowski 1983, 2176.

155 Sandrart 1925, 206.

156 Sandrart 1925, 206.

157 Sandrart 1925, 206. For this aspect in general, see: Pfisterer 2014.

158 Sandrart 1925, 205. Sandrart characterizes his father, Christoph Georg Mayr, as a gentleman and merchant.

159 Cf. Buchner 1929, 175; Cat. Augsburg 1968, 221. Critical on this point was, most recently, Zeeb (2011, 188), even if he proceeded to write (201) that classicist painting, which was applied in an eclectic manner, could be used in combination with other formal elements.

160 Gerson 1983, 275 .

161 Sandrart 1925, 206; Sumowski 1983, 2175; Zeeb 2011, 187 .

162 This can be said, for example, of Jürgen Ovens' Self-Portrait at the Easel (now in St. Petersburg). Ovens displays many structural affinities to Mayr in his work. See Köster 2017.

163 Cat. Dresden 2006, 102-103. On the sheet of Mayr's drawing is written: ' $\mathrm{Zu}$ freudtlichem 
angedencken machte dises / Johan Ulrich Mair in Augspurg 1700-10 Jenner'. This declares the function of the drawing. It was in Johann Jacob Müller's family register, who is probably the person represented on the sheet.

164 Cat. Dresden 2006, 101.

165 Zeeb 2011, 217.

166 Sumowski 1983, 2175 .

167 Bauch 1926, 23 and 36.

168 This does not mean that Rembrandt was no longer a point of reference for those painters. Van der Veen voiced the opinion that 'Govert Flinck must have maintained contact with Rembrandt and his work: for years, he continued quite openly to borrow motifs from the work of his former master'. Jaap van der Veen 2006, 169.

169 Houbraken 1753, vol. 2, 305: 'Nu moest hy zig een wyze van schilderen voorstellen die prysselyk was om zig daar aan te houden. De penceelkonst van Ant. Van Dyk was in groote agting, en die van Rembrant vond ook veel aanhangers. Op dezen tweesprong stond hy lang te dutten, niet wetende wat weg best in te staan, dog verkoos de handeling van den eersten als van een duurzamer aart, tot zyn voorwerp'.

170 Warnke 1991, 84-85.

171 Schmidt-Degener 1928, 3-4. In 1939, Valentiner too spoke of the former Rembrandtists in a very demeaning way: 'Most of these pupils revealed their lack of individuality after having left Rembrandt's studio, when they changed their style abruptly and became artists of so little importance that it is often not easy at all to recognize them in their new mode of expression'. Cited from Bikker 2005, 3 .

Schmidt-Degener 1928, 44. Schmidt-Degener's study on the bipolar nature of Dutch culture was a key point of reference for Aby Warburg's Rembrandt interpretation. Cf. Warburg 2012, 69-102.

\section{Primacy of the Hand}

Van Hoogstraten 1678, 237 f. See Michalski 2011, 189; Hadjinicolaou 2016c.

\section{Although Wöfflin is specifically referring}

to Ludwig Richter's Lebenserinnerungen

(1885): 'Ludwig Richter erzählt in seinen

Lebenserinnerungen, wie er in Tivoli einmal als junger Mensch, zusammen mit zwei Kameraden,

einen Ausschnitt der Landschaft zu malen unternahm, er und die andern fest entschlossen, von der Natur dabei nicht um Haaresbreite abzuweichen'. Wölfflin 1915, 13. Cf. Summers 2013, 42-53.

Van Hoogstraten 1678, 237: '(...) Knipbergen genoemt, stelde een tamelijk grooten doek op den Ezel, en, de hand of 't penseel tot zijn wil hebbende, begon dapper te schrijven, dat is, op zulk een aengewende wijze te schilderen, dat al wat hy ter needer zette, gedaen was'. It is not a coincidence that Knipbergen is compared to a writer who assimilates everything in his work but who, on the other hand, practices simple imitation.

Van Hoogstraten 1678, 238: 'De derde was onzen Parselles, dien grooten Raphel in 't zeeschilderen! Maer de liefhebbers gaeven den moedt bynae verlooren, als zy zagen hoe traegelijk hy met zijn penseelen handelde (...) om dat hy eerst in zijn inbeelding 't geheele bewerp van zijn werk formeerde, en in zijn verstandt een schildery maekte, eer hy verw in 't penseel nam'.

Van Hoogstraten, 237: '(...) of dat het oog in de ruwe schetssen van gevallige voorwerpen eenige vormen uitpikt, gelijk wy aen den haert in het vuer pleegen te doen; of dat de handt, door gewoonte, iets formeert, min noch meer als wanneer wy schrijven; want een goedt schrijver maekt goede letteren, schoon hy 'er niet aen gedenkt, en zijn oog en verstandt schijnen in zijn hand geplaetst te zijn' [author's italics]. Cf. Van de Wetering 2004, 85-86.

Van Hoogstraten 1678, 237-238. Translation in Weststeijn 2008, 251: '(...) want hy zijn geheel paneel in 't gros overzwadderende, hier licht, daer donker, min noch meer als een veelverwige Agaet (...) en in 't kort zijn oog, als op het uitzien van gedaentens, die in een Chaos van verwen verborgen laegen, afgerecht, stierde zijn hand en verstandt op een vaerdige wijs, zoo datmen een volmaekte Schildery zag, eermen recht merken kon, wat hy voor hadt'. Luca Giordano's manner of painting resembles that of Van Goyen. Cf. Damm 2011, 145-170. In both cases it is clear that rapid execution was viewed in terms of economy. Cf. Powell 2017.

$7 \quad$ Cf. Clark \& Chalmers 1998, 7-19; Clark 2008. For a comprehensive introduction on the philosophy of embodiment, see Fingerhut et al. 2013. 
However, caution is also called for in regard to the notion of the 'extended mind'. Rather the union of hand, utensils, thinking, and artefact or environment must be understood as in unison with the mind and not merely as an extension of it. For the intelligent hand playing a similar role for creating ideas in Italian art theory, see: Pfisterer 1993, 237-268. On the term disegno, see: Kemp 1974, 219-240; Cat. Berlin 2007. Giovanni Battista Paggi denies that the hand is important in artistic processes and instead holds onto his idealist-oriented programme: 'The operations of the hand, if it is an intelligent one, is of so little worth that not much should be made of it. (...) Art lies in the intellect and not in the hands'. See Romano 1989, 97. Cf. Preimesberger 2003, 220-227. Cf. Broos 1971, 174-175: 'Dit's Koppenol na 't leeven / Men kan niet meerder geeven / De schrijfkunst en 't verstand t/ Behouwdt hij in zyn hand'.

Cf. Doni 1549, quoted after Warnke 1997b, 113. On the thinking hand, see: Bredekamp 2007, 12-24; Pallasmaa 2009; Bredekamp 2015. For a general history of the hand, see: Bondio Gadebusch 2010. Warnke 1997b, 120.

13 Weststeijn 2011, 209: '(...) the Italian has brains in his head (...) the Netherlander has wit in his hand'. Lampsonius' critical claim is quoted after van Mander: 'Want den Italiaen heeft d 'hersens in zijn hooft/ (...) de Nederlander/Heeft in zijn handt vernuft'. This is not meant without criticism. Roodenburg 2004, 12. See Van den Akker 1991, 127-148 and Sennett 2008.

Krois 2011c, 253-271.

17 Neuweiler 2007, 17. In another publication the author underlines the movement of hands and their gestures for the development of the cerebral cortex. Cf. Neuweiler 2008.

Gockel 1999; Krüger 2007.

19 Busch 2011a, 173. The role of the instrument as an intelligent organ and determinant of artistic experimentation is analogous to the utilization of scientific instruments in scientific experiments. Cf. Wind 2001. For the role of instruments in art, see: Cordez \& Krüger 2012.
Van Hoogstraten 1678, 27: 'Overzie in een tronie vry de byzondere leden, ten waer gy alleen met losse streeken de holachtige schaduwkens, van oogen, neus, of mond, die zich voornamentlijk vertoonen, aenweest; doch dat dit niet te vroeg, en buiten haer behoorlijke plaets geschiede. Deeze manier van in 't gros te schetssen, is by de meeste op een onbedwonge wijze in 't gebruik, maer sommige hebben zich aengewent, met rechte streekjes, de voornaeme gedeeltens in vierkantachtige, langwerpige, en in hoekachtige formen, doch niet geheel toegehaelt, te begrijpen. Ik laet dit aen de keur des leerlings: maer wat verder het ruw schetsen belangt, het is de eerste grontvest van 't wel teykenen (...)'. Cf. Van de Roemer 2011, 199. One thinks of Leonardo's macchia. On this question, see: Hadjinicolaou 2017.

Karel van Mander's dictum of two 'manners of handling' here comes to mind, in which he recommends that young artists or lovers use the fine manner, but leaves it for them to judge for themselves which they will adopt in the end. Hirschfelder 2013, 201.

See Chapter VI.

De Moor 2011, 58: '(...) niets is so slim als de slimheid die je overvalt tijdens het werk'.

Cited in Stückelberger 2006, 117. See Busch 1995, 209-228 (esp. 209 and 220); Cat. Frankfurt 2007, 73. Rosenberg reminds us of the fact that Cozens, in 1759, 'highlighted intention in extracting from blots', placing the emphasis on accident in keeping with the time around 1785 . Cf. Gamboni 1999, 206.

Van Hoogstraten 1678, 27: 'En even gelijk men zijn vriend van verre bespeurende, of by schemerlicht ontmoetende, strax als met het verstant zijn gedaente ziet, en bevat, zoo geeft een ruwe schets dikwils aen den kenders zoo grooten indruk, dat zy 'er meer, dan dieze gemaekt heeft, in zien kunnen'.

Atkins 2012, 92-94. On the problem of 'unfinished', see: Chapter IV.

Atkins 2012, 92. Van Hoogstraten 1678, 240: 'Antidotus schilderde ruw, maer miste dikwils in de maetschiklijkheyt. Ten zijn niet al Nikomachen, die een vaerdige handt hebben: nooch Tyntoretten, die stout in 't penseel zijn, De deugt van 't werk bestaet in bevallijke natuerlijkheyt, en als men die met haest onmachtich is, zoo behoort men 'er tijdt toe te nemen'. Slive 1988, 129. In another context Edgar Wind commented on the working method of Friedrich Schlegel: 'Comparing rough drafts of philosophy to the sketches (...) he proposed to sketch 
philosophical worlds with a piece of chalk, or characterize the physiognomy of a thought with a few strokes of the pen'. Wind 1985, 39. For the relationship between Gaston Bachelard and artist Albert Flocon, see: Rheinberger 2016.

Cf. Korthals Altes 2009/10, 197.

Imdahl 2003, 90.

Cf. Michel 2009/10, 212-225.

Frank 2008, 217.

Krüger 2007, 195.

In this context Max Liebermann commented that 'art does not lie in the idea but the execution of the idea. Rembrandt retorted, when his pupils asked him how they should paint, that they should take up the brush in their hands and begin'. Cf. Stückelberger 1996, 79 .

Kruse 2003, 75. Balzac summed this up in Chefd'oeuvre inconnu as follows: 'Painters should only meditate brush in hand.' See: Balzac 1984, 21;

Didi-Huberman 2002, 160.

Reynolds 1997, 223. Cf. Van de Wetering 1998, 35. Cf. Smith 2004, 54. See: Chapter III, 136-137. Gockel 1999, 166-167.

Boomgaard \& Scheller 1991, 114.

Chapter III, 110.

Castiglione 1907, 42. Cf. Rosen 2003, 348. See: Burke 1996. Cf. Weltzien 2011, 21; Roodenburg 2004; Pousão-Smith 2004, 259-279. Pousão-

Smith, strangely enough, links sprezzatura only to the work of fine painters such as Dou and not Rembrandt.

Sohm 1991, 247. The original is in Venetian dialect.

Sohm 1999, 109.

Thompson 2010, 249-251.

Ghiberti 1912, vol. 1, 62 and vol. 2, no. 189: 'Ancora uidi in Padoua una statua, ui fu condotta per Lombardo della Seta; A moltissime dolceze le quali el uiso no lle comprende nè con forte luce nè con temperata, solo la mano a toccarla la truoua',

Braungart 2005, 31. Henkel \& Schöne 1967, 10101011. Visscher carried on the tradition already found in Andrea Alciato's Emblemata, which was first printed in Lyon in 1551. See Melion 1993, 6o-94.

49 Henkel \& Schöne 1967, 1010-1011. The epigramm of the emblem states: 'Many do not know when to call it a day and do not stop until the cock crows and there is nothing left to drink' translated from the German: 'Viele scheiden nicht auf dem Höhepunkt des Festes und wissen nicht wegzugehen, ehe das Getränk beim Hahnenschrei ausgeht'.

Brusati 1995, 149 .

Hoecker 1916, 3 and 31 .

For the role of intuition, see: Hogrebe 2006.

Brusati 1995, 149.

The emblem in Visscher goes on to say that 'Voor alle Edelheyd gaet de wackere Dapperheydt, 'twelck beteeckent wordt door een wakent Oogh in de handt, boven den Lauren krans; want Edelheydt van Geboorte is wel een spoor of prickel tot treffelijke daden, dan de trage Slampamper mach hem zijns gheboorts niet roemen, als hy de dappere handt niet aen 't werck en slaet, toonende dat hy zijns gheslachts gheen bastaert en is. Ende die van slechte afcomst is, behoeft hem dies niet te schamen, den wegh van eeren staet hem oock open, soo hy in Dapperheydt d' Edelheyd overtreft ende te boven gaet'. Visscher 1614, vol. 2, 8, quoted after Henkel \& Schone 1967, 1010-1011.

It was not a coincidence that Sandrart saw diligence as a key characteristic of Rembrandt. Sandrart 1675, I, vol. 3, 58, under: http:// ta.sandrart.net/de/text/145\#tapagehead [22 Jan. 2014].

$5^{6}$ Tunstall 2011, 181; Dethlefs 2010, 314. Cf. Hecht 1984, 131: 'De Piles, obviously drawing on Baldinucci for the bare bones of the story, asserts, that he has seen a portrait of Gonnelli in Paris in which the poor prodigy was portrayed with an eye on each fingertip (...) to indicate that his original eyes were no longer of service to him'. The blind sculptor verifies, in this case, the role of tactus in relation to visus in the purported debate on the relative merits of painting and sculpture (paragone). Cf. Körner 2013, 144.

Pallasmaa 2009, 31: 'this complete integration of the actions of the hands with the entire body'. Vinzent of Beauvais evidences that this topos is quite old, that is, it existed around 1250 . He understood the hand to be a 'gift to the whole body'. Cf. Löhr 2008, 154.

Boehm 2007a, 157.

59 Van de Roemer 2011, 195.

6o Van de Roemer 2011, 195 .

$61 \quad$ Warnke 1997b, 112.

62 Sandrart 1675,62 , under: http://ta.sandrart.net/ edition/text/view/149\#tapagehead [22 Jan. 2014].

63 Pallasmaa 2009, 82-86. 
Cf. Malafouris 2013.

Van de Wetering 2010, 119: 'So it is now necessary that one should get used to a way of doing such that it is able to obey readily what the mind dictates'.

Van de Wetering 2010, 48. Dürer described the role of the hand in relation to the intellect as follows: 'The intellect must grow through employment, therefore the hand does what is willed by the intellect' ('Dann der Verstand muß mit dem Gebrauch anfahen zu wachsen, also daß die Hand künn thon, was der Will im Verstand haben will.') Cited in Wagner, no. 32, 197.

Van Hoogstraten 1678, 63. Cf. Van de Wetering 2010, 47-48.

Quoted after Suthor 2010, 252: 'Gy moet maar stout toesmeeren: als gy vast in de Konst word zal de netheid van zelf wel komen'. In a sense this had already been highlighted by Cennini: 'Do you know what will happen to you if you draw with a pen? It will advance your skill, make you adept, and give you the ability to do a lot of drawing in your mind'. Cf. Löhr 2008, 168. Training the motor skills by drawing can elicit ideas for future works. Löhr (169) emphasized the importance of the interplay of intellect and practice to kindle the imagination.

Brusati 1995, 225.

Cf. Bakker 1995, 159-162. The term appears already by Van Mander, cf. Hoecker 1916, 28. Van de Wetering 2010, 216.

Sohm 1991, 116.

Van de Wetering 2010, 12.

Houbraken 1753, vol. 2, 158-159. Cf. Kern 2012, 113. See Horn 2013b, 241-258.

Cat. Wolfenbüttel 2008, 65 .

Henkel \& Schöne 1967, 1011; Braungart 2005, 31.

Cf. Zapperi 1990, 123-138.

Weststeijn 2008, 72.

The agency of the hand is a decisive factor, as Jakob Böhme pointed out in Aurora: 'Hands symbolize the omnipotence of God. Analogous to how God can transform nature and do whatever he wants with it, humans can, with their hands, transform everything that grows in nature or is part of it according to their will. In this way, they reign over the works of nature and its creatures and verily represent God's almightiness'. Böhme 1974, 71-72. Cf. Smith 2004, 161.

Smith 2004, 220. David Rosand summed up the problem in Drawing Acts: 'It is by lending his body to the world that the artist changes the world into paintings'. Rosand 2002, 15.

Roodenburg 2012, 93-105, especially 97-100. Cf. Mauss 1975, vol. 2, 199-220; Bourdieu 1993, 161-175.

Merleau-Ponty 1966, 233-235; Cat. Wolfenbüttel 2008, 1.

Focillon 1958, 20 and 25. Focillon 1989, 158-164. Focillon 1989,180 and 184.

Cranston 2010, 16.

Van Hoogstraten 1678, 22 'Zeeker de Schilderkonst bestaet in wel te doen, en niet in wel te zeggen'; on page 230 he repeats: 'houd meerder van doen, dan van zeggen'.

Cf. Taylor 2008, 161; Weststeijn 2013c, 23. This was Annibale Carracci's opinion, as seen above.

Neumeister 2010, 104.

Neumeister 2010, 109.

Neumeister, 112.

Gage 2009, 182.

The term bruin is used for hues of this kind, which does not mean 'brown', but dark shades of colour.

Kern 2012, 111. See also Kern 2014.

94 Białostocki 1966b, 49-6o; Blankert 1973, 32-39; Mai 1998, 98-109; Mai 2002. According to Mai, De Gelder is referring to the anecdote about Zeuxis passed down by Marcus Verrius Flaccus and related in Karel van Mander's Schilderboeck (1604). Blankert 1973 .

Cat. Cologne \& Dordrecht 1998, 174.

To date, this detail has been overseen in literature. Cf. Pfisterer 2007, 45-53. The tradition of creating grotesques out of the accidental folds in clothing can already be found it the art of the Middle Ages.

Quoted after Dethlefs 2009, 219.

Baldinucci 1686, 79: 'Lo scomparire, che faceva in lui una faccia bruta, e plebea, era accompagnato da un vestire abietto, e fucido, essendo suo costume nel lavorare il nettarsi i pennelli addosso, ed altre cose fare tagliate a questa misura'. Cf. Slive 1988,113 . In addition, it must not be forgotten that Sandrart emphasized Rembrandt's lowly origins in his biography of the artist: '(...) der fürtrefliche Rembrand von Ryn/nur aus dem platten Land und von einem Muller entsprossen (...)'. 
Sandrart 1675, I, 326, under: http://ta.sandrart. net/de/text/552\#idx552.1 [20 May 2015].

Lomazzo told the story of Dürer (as a sign of his humility) walking along the streets of Nuremberg in his painting smock. Lomazzo 1590, 114-115: '(...) D’Alberto Durero si dice che spesse volte andava per la città con la veste nelle quale pignea, non riputandosi niente più del suo valore (...)'. Cf. De Winkel 2006, 163. See Raupp 1984, 180.

De Winkel 2006, 162

Weyerman 1729, vol. 3, 44 .

Neumeister 2010, 108.

Neumeister 2010, 111.

Cf. the third part of this Chapter, 95-97.

Golahny 2003, 204-205. Van Hoogstraten mentions the grapes painted by Zeuxis and how they deceived the birds.

Cf. Van Hoogstraten 1678, 215: 'Door naeryver quam Zeuxis tot zoo hoogen graet in de Schilderkonst, dat de vogelen door zijn geschilderte druiven bedrogen wierden'. Cf. Cat. Cremona 1996, 214-219; Fusenig \& Vogt 2006, 104-106.

Von Wurzbach 1970, 115 .

Slive 1988, 163.

Weber 1991, 126.

Weber 1991, 17.

Weber 1991, 131. See De Lairesse 1817, vol. 1, 286. In this context Murillo's paintings of children would be another example. De Lairesse in fact refers to them too in another passage. Cf. Zakula 2011, 165-173.

Thomas Gainsborough to David Garrick, May 1766. Sloman 2011, 27 and 35. See Gockel 1999, 27. On Gainsborough cf. Busch 2010, 87-89.

Hecht 2006, 14.

Quoted after Liedtke 1997, 125.

Smith 2004, 8: 'Artisans employed naturalism in order to make claims about their status as active knowers. (...) The articulation of this epistemology through naturalistic objects and paintings in turn influenced patrons and scholars in their attitudes toward nature'. This is what Smith calls the 'epistemological status of craft operations' (21).

7 Quoted after Smith 2004, 100. On page 113 Smith is even more specific: 'the whole body was in artisanal labour'.

Cf. Conti 1998. The present study deviates decidedly from a linear development from 'craftsman to virtuoso'.
119

120

121

122
Weigel 2006, 239.

Dante: Monarchia I, iii, 9 and ii, 1. Quoted after Löhr 2008, 169 .

Sumowski 1983; Cat. The Hague 1992.

De Vries 2011, 117.

Becker 1991, 106. Cf. Puttfarken 1985, 67-68.

De Piles 1706, 262.

De Piles 1706, 297. Becker 1991, 107. It goes without saying that Rubens was very different to Rembrandt both at a social level and in regard to their painting, even if the latter consciously competed with the former. However, from the angle of the French academic painting tradition, Rubens and Poussin were opposites in the design versus colour debate, that is, what in Holland was represented by Rembrandt and Van der Helst. Cf. Cat. Arras \& Epinal 2004.

Houbraken 1753, vol. 1, 273: 'Alk ik myn geest uitspanninge wil geven, dan is het niet eer die ik zoek, maar vryheid'. Sandrart already noted that Rembrandt would associate with people of the lower classes. Slive 1988, 93.

Houbraken uses the adjective 'bürgerlich' (middle-class) in the sense of humble: '(...) daar hy maar borgerlyk leefde'. Houbraken 1753, vol. $1,272$.

De Piles 1715, 424: '(...) ce n'est pas l'honneur que je cherche, c'est la liberté'. De Piles 1715, 422. Quoted after Slive 1988, 216 and 126: l'éducation et l'habitude ont beaucoup de pouvoir sur nos esprits'.

Cf. Slive 1988, 126; Horn 2000, 476. It is not that relevant to be able to verify if what is said of Rembrandt is true or not. It is, nevertheless, informative because it reveals how he was pigeonholed by his contemporaries.

De Piles 1706, 318.

Boschini 1966, 99 quoted after Sohm 1991, 138. Cf. Suthor 2010, 214, on Rolin stating the opposite in France by considering freedom of the hand as having its problems.

Mai 2006; Cat. Cologne etc. 2006. Both approaches describe the change from the old to the new manner, but the ideological implications of the visual language used by the Rembrandtists is not addressed.

Watelet/Lévesque 1792, vol. 3, 379, quoted after Suthor 2010, 246-247.

Frank 2008, 218.

De Vries 2011, 21. 
Quoted after de Vries 2011, 30 and 143. See De Lairesse 1712, vol. 1, 16 and 260.

136 Kemmer 1998, 92 and 97; De Vries 2004, 8 o.

137 De Vries 1998, 126.

138 De Vries 2004, 81.

139 De Lairesse 1712, vol. 1, 7. Cf. De Lairesse 1778, 1: 'vloeijende' and 'gladde', 'wakkere', 'vaardige', or 'stoute'. De Lairesse 1712, vol. 1, 8. Cf. De Lairesse 1778, 2: 'echter styf en morssig schilderen'.

De Vries 2011, 56; De Lairesse 1712, vol. 1, 173. In another passage of his Schilderboek (p. 325, cited in Van de Wetering 2010, 129) De Lairesse admits: 'I don't deny that I once had a special preference for his [Rembrandt's] style. But as soon as I began to understand the infallible rules of art, I had to acknowledge this aberration and reject his style as something resting on nothing but disordered flights of fancy (...) [it has] no solid foundation to support [it]'. See Zakula 2015.

De Lairesse 1712, vol. 1, 41-43.

See Chapter IV, 163 .

De Lairesse 1712, vol. 1, 196. Cf. De Lairesse 1778, 113-114: '(...) want hoe bespottelyk zou het zyn, indien men de Koningin Esther kwam te kleeden in een naauwe en styve tabbaard (...)'. In this regard De Vries $(\mathbf{2 0 1 1}, 123)$ sees a correspondence between the comparison De Lairesse makes and the paintings of Jan Steen. David de Witt refers, with Houbraken, to the bearing of De Gelder on Jan Steen, so that, at least here - and regardless of the issue whether De Lairesse meant Steen or De Gelder with the passages quoted above - it is justifiable to speak of a structural similarity. See De Witt 2003, 88-9o.

De Lairesse 1712, vol. 1, 320 and 324. Cf. De Lairesse 1778, 193 .

145 De Lairesse 1712, vol. 1, 325. Cf. De Lairesse 1778, 193.

146 De Lairesse 1712, vol. 2, 17-18. Cf. De Lairesse 1778, 270-271. For Rembrandt's reception of Titian, see: Van de Wetering 1991, 12-39.

147 Translation: De Lairesse 2011, 195. De Lairesse 1712, vol. 1, 185: 'Zo zag men Rubbens en van Dyck, mannen die dagelyks te Hoof en by de Grooten verkeerden, hunne gedachten op her verheevene der Konst vesten; Jordaans en Rembrant weder op het burgerlyke; Bamboots en Brouwer op het allergeringste: en dus ieder na de maat hunner neigingen, voor zo veel dezelve tot den ommegang met menschen van hunne soorten strekten'.
148 De Vries 2011, 15: '(...) critics associated his painting style with his supposed lifestyle'. Id., 173 .

149 Emmens 1979, 273; Raupp 1983, 407. De Lairesse is certainly not the first to divide artists into three styles and three types of artists. Melanchthon already spoke of the genera dicendi in regard to Dürer, Cranach, and Grünewald. Cf. Weniger 1932, 21. In Teutsche Akademie Sandrart undertakes a tripartite division based on the three genera dicendi for the different architectural orders of columns. Cf. Von Sandrart 1675, 13-15, under: http//ta.Sandrart.net/de/text/62 [26 Dec. 2015].

Woodall 1997, 76 .

Burgerlijk, WNT 1902, vol. 1.

Cf. Dolders 1985, 197-220; Busch 1993, 317-319;

Roodenburg 2004, 124-126.

153 De Lairesse 1712, 55. Cf. Taylor 2010, 13-14: 'Maar zie nu eens deze aanzienelyke Juffer, hoe zedig haare beweeging en hoe groots en bevallig haare gestalte is, de eene hand rust onder de borst tegen het lyf, het binnenste des hands bovenwaards gekeerd, laatende de vingers los en slapjens nederwaard buygen, terwyl zy, aandachtig luysterende, met de andere een slip van haar kleed eenigzins opbeurd; zy staat recht overend, het hoofd zyling een weinig voorwaards geboogen, de knien en voeten dicht aan een, en met de eene hiel tegens de binnenste enkel van de andere voet gekeerd. Stel nu die andere vrouw daar by staande en desgelyks aandachtig toehoorende, eens in teegen overeenstelling met de voorige, en let wat een verschil de opvoeding in de gebaarden der mensen maakt; beide haar handen heeft zy op de heupen gezet, staande op beide de voeten zonder de minste draaying, het boovenlyf held een weinig voor over, de borst en kin steekt zy vooruit, slaande het hoofd wat in de nek, met de mond eenigzints gaapende, en geen zwelling der heupen'. A middle mode seems to be missing in this case. The three different modes are each demonstrated by two illustrations. The forms of the respective glasses, as well as the respective hands, characterise the respective modes (uncouth, elegant, and graceful).

156 Burke 1994, XX.

157 Weststeijn 2008, 193.

158 Van Hoogstraten 1678, 198. Van de Wetering 2010, 96: '(...) hoemen de figueren een behaeglijke sprong zal geeven, dat is, datze, 't zy hoog of 
laeg, met malkanderen een gedaente maeken, die 't oog bevallijk is, en datze, door haere verscheydenheyt onderling schijnen te speelen'. Translation Herman Roodenburg. Dolders 1985, 185. Presumably De Lairesse hoped, like his readers - who were of the same class as himself, that the middle classes would be 'elevated' by means of ideals prevailing at the court generally taking hold, which can be seen in his self-presentation as if he were a member of the aristocracy.

16o Dolders 1985, 185 .

161 It is revealing that De Lairesse distinguished between the modern and the ancient, which can be reformulated as the 'momentary' in contrast to the 'classical': De Lairesse 1712, vol. 1, 173. Quoted after Atkins 2012, 197: 'I think I cannot better describe the difference between what is antique and what is modern, than by a windball and an egg, thus: the ball by being tossed to and fro, and at last bursting, represents short duration, affording nothing but wind; but the egg hatched and opened, produces a living creature; not only a something, but something good; the former, a mere nothing; or, if it have a name, 'tis vanity, and therefore rather bad than good'.

162 Dethlefs 2009, 221-222. Sandrart, for example, makes comments on habits concerning how artists dressed themselves (Von Sandrart 1675, Chapter 12). Clothing must be appropriate to gender, rank, and occupation as well as national customs.

163 Van Hoogstraten 1678, 176. Cf. Van de Wetering 2010, 59: 'Wat ons aengaet, wy geeven deze, en, zoo 'er noch meer verschillende geesten zijn, yder de vryheyt haer behaegen te volgen; en verwerpen geen tulp om dat het geen roos, noch geen roos om dat het geen lely is. Wy zullen de konstdeelen verhandelen, een yder verkieze daer uit, 't geen hem waerdichst dunkt'.

164 Montaigne 1992, 817. Quoted after Cat. Wolfenbüttel 2008, 114 .

165 The term 'genre' is coined only much later. Cf. Gaethgens 2003, 14-44.

166 Slive 1988, 170-171.

167 Ten Kate $1869,7-8$. Quoted after Slive 1988, 170-171: 'Schoon Rembrand zyne denkbeelden van laage en gemeene beelden, zo ten aanzien der kleedinge, gelaat als gestalte, ontleend schyn te hebben; egter geeft hy, door een kunstige verdeeling van licht, om dezelven beter te doen uitblinken, gewoonlyk aan zyne eenvoudige beelden spreekende vrolykheden en gemoedsbeweegingen, verzeld van eene gemaklyke en ongemaakte houding; doch dit alles heeft zelden iets deftigs'. Translation Herman Roodenburg.

168 Chapter v, 230-235.

169 Cat. Dordrecht 1992, 166-167; Cat. Dordrecht \& Cologne 1998, 230-231. Here in the sense of the painter's stylistic development, which is not pursued in this study.

This kind of regulation of the lighting had a technical aspect, as when the studio received light from the south, it could be softened by means of the curtain. Cat. Dordrecht \& Cologne 1998, 230.

171 Cat. Dordrecht \& Cologne 1998, 230.

172 Sohm 1991, 206 (Boschini 1966, 374-375).

173 See Chapter III and Chapter IV.

174 Cf. Leonhard 2013, 85-91.

175 Kern 2012, 111; De Vries 2011, 38: 'bruyn as a meaning of dark, not brown, schoon (pure)'.

176 De Vries 2004, 9o: 'Laat u niet vorstaan dat de gloeijende en bruyne Coloriet de beste zy'.

177 Kern 2012, 111-113.

178 Kern 2012, 111-113.

179 Quoted after Gerson 1973, 209: ‘(...) so ist Herr Görling gewaltig gerupft, da ihm ein Weiberkopf, der allem Aussehen nach von Arent de Gelder, einem der jüngsten und wohlfeilsten Discipel des Rembrandt ist, vor Rembrandt aufgehängt worden, und ihm dagegen ein Netscher und zwei Cosciau abgelockt, wo Netscher allemal den Rembrandt, wenn er auch ächt wäre, an Wert übersteigert'. Cf. Gerson 1983, 266. On page 343, Gerson writes that 'the Rembrandt Renaissance began in the second half of the seventeenth century. Its roots were in the movement against Rococo art, which determined and defined it'. This opinion upholds Hagedorn's.

180 It is characteristic that Samuel van Hoogstraten on the title page of the seventh book of the Inleyding represents Hephaistos with Melpomene after being liberated from the darkness as a mere artisan so as to legitimize his school of painting in the grand manner. Apollo welcomes the painter in an orb of light and thus represents true knowledge. Van Hoogstraten $1678,242-243$. 


\section{Art Materials}

Wagner 2002. See Wagner et al. 2010. Cf. Hadjinicolaou 2013, Hadjinicolaou 2014a. Wagner 2002, 22.

Wagner 2002, 18. It can very likely be evidenced that also during the Middle Ages - and indeed even among the Ancients - artists made a conscious decision as to which materials they employed. In Byzantine art, there are many examples that inform about the appreciation and reception of materials as such. Wagner 2002, 18-19. Cf. Bandmann 1969, 75-100; Gramaccini 1987, 147-170; Sheard 1992, 63-93; Penny 1993; Raff 2008; Anderson et al. 2014. Wagner begins her 'alternative history' with Turner. Cf. Wagner 2011. Matthias Krüger examined this process for the latter half of the nineteenth century in France. See Krüger 2007. Uhlig 2000, 231.

8 Wagner 2000, 109.

Ulrich 2000, 94-95. John Dewey put this in a nutshell by commenting that '(...) the contrast is not between matter and form but between matter relatively unformed and matter adequately formed'. Dewey 2005, 198. In 1802 the painting was sold as part of the collection of the Polish king at an auction in London, and the Dulwich Picture Gallery purchased it in 1807 , where it still is today. William Hazlitt (1824) and James Russell Lowell (1855) were enthusiastic in their remarks on what was believed to be a Rembrandt at the time. The work inspired Turner in his Vision of Jacob's Ladder. The attribution of the painting at the Dulwich Picture Gallery to Rembrandt was first negated in 1946 (after discovering the signature scratched into the paint), when it was finally ascribed to Aert de Gelder. Cf. Van Fossen 1969, 32 f.; Loughman 1998, 246. On the term plasticity, see: Rübel 2012.

directly out of the tubes'. Van Gogh-Bonger 1963, no. 221. Quoted after Wagner 2002, 30. Cf. Sumowski 1983.

In this context Hans Joachim Raupp speaks of an 'ingenious turn of the head' of the artist, which has its point of reference in Rembrandt's selfportraits. See Raupp 1984.

Cat. Freising 2007, 216.

Van de Wetering 2005, 89-317. See also Cat. Washington 2008 and Schnackenburg 2016. Cat. Freising 2007, 256.

Cat. Freising 2007, 185-186.

The motif in the work seems to be a playful adaption of one borrowed from Albrecht Dürer's copperplate engraving The Dream of the Doctor (c. 1498), as the demon has been replaced by an angel, and the doctor, abandoning himself to idleness, has been substituted with a despondent St. Jerome.

The only exhibition devoted to this artist alone alludes to this fact in its title: Christopher Paudiss 1630-1666: Der Bayerische Rembrandt? (2007). Von Sandrart 1675, 70-71: 'Hier hat der Mahler insonderheit zu beobachten/ wie die entlegene Landschaften sich algemach in der Farbe verweiten und verlieren. (...) die Bäume und ihre Blätter theils rötlich/ theils gelb/ coloriren/ und Form und Farben sich veränderlich zeigen: welches dann den Gemälden große Anmutigkeit gibet (...) Mahlen ist besser/ als Zeichnen/ nach dem Leben'.

Houbraken 1753, vol. 1, 259: '(...) zoo ver dat hy om eene enkele parel kragt te doen hebben, een schoone Kleopatra zou hebben overtaant'.

Cf. Emmens 1979; Slive 1988.

Houbraken 1753, vol. 2, 158-159: 'Daar en boven had hy een manier van vet in de verf te schilderen, een wyze van doen, waar door de stukken lang hunne volkomen kragt en koleur behouden (...) als dat de koleuren, in de kleederen inzonderheid, te enkel en onvermengt gebruikt zyn (...) somtyds dingen in zyn stukken gebragt heeft, die hy in zyn Boek van de gronden der Schilderkonst wraakt'.

observations, who claimed that the brush-
strokes appeared to be abstract elements that bore no optical resemblance to anything else. Cf. Atkins 2012, 151. A statement of Van Gogh's displays amazing parallels to the techniques and application of paint for the trunks of the trees in Jacob's Dream: 'I pressed (...) the roots and trunks

Van de Wetering 2010, 72 and 98.

Nicolaissen 2004, 34.

Hoecker 1916, 280. Cf. Van de Wetering 2010, 115: 'En blijft dan niet, als moetwillighe Secte/ Aen u valsch' opiny te vast ghebonden/Maer overspeelt hier vry/ ten zijn geen zonden'. 
Van Hoogstraten 1678, 30 and 234-235: '(...) $[\mathrm{w}]$ ant men moet zijn handeling nae den aert der dingen somtijts veranderen. (...) Een yder ding zijn eygenschap te geven, In 't handelen: men wen zich geen manier, Als die zich strekt tot aller dingen zwier. (...) Bekreun u weynich met een handeling of manier van schilderen te leeren, maer wel, om gestadich in de opmerking vaster te worden, en de deelen der konst wel te onderscheyden, en met wakkerheyt nae te volgen. (...) Want daer behoort een andere lossicheit van handeling tot het luchtige hair (...)'. '(...) one must sometimes change the handeling according to the nature of things (...), give everything its own quality in the handeling after its character in life acquiring no other manner than that which extends to giving everything its natural quality. (...) Do not bother much with learning a particular handeling or manner of painting, but do so to become firmer in your observation and to distinguish the different parts of the art and imitate them carefully. (...) a different kind of brushwork is needed for fluffy hair'. This passage was quoted in Chapter I for its relevance to handeling. However, in the present context it gains yet a further dimension. Cited in Van de Wetering 2010, 122-123.

29 Spinoza defines these two key terms in his Ethics as follows: '(...) by natura naturans we are to understand that which is in itself and is conceived through itself, or those attributes of substance which express eternal and infinite essence, that is to say (...) God in so far as He is considered as a free cause. But by natura naturata I understand everything which follows from the necessity of the nature of God, or of any one of God's attributes, that is to say, all the modes of God's attributes in so far as they are considered as things which are in God, and which without God can neither be nor be conceived'. Spinoza 2001, 28.
Roger de Piles generally deplores a heavy hand.

Rather, the artist's hand should operate in a loose and easy fashion in the sense of sprezzatura, a topos since C. Cennini. Cf. De Piles 1706, 39: 'In this place the word pencil signifies simply the exterior manner he observe'd in employing his colours, when those colours don't seem too much agitated, or, as one may say, too much tormented by the motion of a heavy hand; but on the contrary when the movement appears free, ready and light, we say, The piece is of a good pencil, yet this freedom of the pencil is of little worth, if 'tis not guided by the Head, (...)'. Cf. Cat. Vienna \& Venice 2007.

32 Daniela Bohde has eloquently described the nature of these aspects of Titian's painting in regard to The Flaying of Marsyas: 'Paint and Materiality are interconnected. (...) Paint is seen more in the sense of its materiality'. Bohde 2002,13 . As ascertained in the paintings of the Rembrandtists, the canvas plays a key role as a support in Titian's painting: 'The texture of the weave is very important and the material basis of oil painting, the support, is not hidden from view. Instead the paint, the brushwork, and the canvas are all made visible and contribute to the effect of the painting. (18).

33 Bohde 2002, 346. Cf. Didi-Huberman 2002; on the term 'incarnazione', see: Kruse 2000, 305-325.

34 Amann 2007, 40.

35 Cat. Cologne \& Dordrecht 1998, 144.

36 'Occasionally he rubbed in the last touches with his fingers. (...) And as Palma assured me, it is true that he, while finishing his paintings, worked more with his fingers than with brushes. Indeed, he worked in this way very rationally. He sought to imitate the operations of Our Creator and formed the human body out of clay with his hands'. Boschini 1966, 711-712. See Von Rosen 2016. Cf. Busch 2009, 99 and 130.

37 For sculpted heads as attribute of the sculptor's trade in portraits, see: Kanzenbach 2007.

38 Ruempol 1982; Cat. Dordrecht 1992, 170.

39 Houbraken 1753, vol. 3, 269: '(...) ik [Arnold Houbraken], verzeld met den Konstschilder Arent de Gelder, en den braven Beeldsnyder Henrik Noteman, hem [Augustinus Terwesten] daar ging bezoeken'. Here Houbraken describes how he, together with De Gelder, visited the sculptor Noteman and Augustinus Terwesten in Dordrecht while they were at work, the latter painting his Ovid series for the Barthout van Slingelandt family.

$40 \quad$ Weyerman 1729, vol. 3, 43 .

41 Cat. Cologne \& Dordrecht 1998, 190.

42 Weyerman 1729, vol. 3, 43-44: 'Dat konterfijtsel was gelyk aan het leeven, en een hand die een hamer had gevat was zo rond geschildert datze buyten het stuk scheen te komen. Nevens dat konstryk konterfijtsel hing een portret van Godefried Schalken, dat een kwade nabuur had 
aan het konterfijtsel van A. de Gelder, want hoe schoon het ook was opgeschikt, echter vertoonde het zich zo plat als een pannekoek van den Vastenavont'.

For the bibliography concerning this image, see: cat. Cologne \& Dordrecht 2015, 158-160.

Cf. Sevcik 2015, 67.

For another interpretation of the paragone debate, see: Van Gastel et al., 15-47.

Hadjinicolaou 2018b. It is remarkable that only the term antagonism is used in English or German, and not synagonism.

Sumowski commented on this, saying that the paint reliefs produced the brightest lights.

The qualities of 'materiality and the ethereal, of mass and transparency, of gravity and ease', as fittingly described by Sumowski, are the key characteristics of both De Gelder and Willem Drost's painting. Sumowski 1983, vol. 4, 2314. Cf. Vogel 2007, 199.

Nicolaissen 2004, 25.

Van de Wetering 2004, 155-159.

Houbraken used the Dutch word geboetseerd, which is very close to the verb bozzare.

Houbraken 1753, vol. 1, 269: 'Ook word 'er getuigt dat hy eens een pourtret geschildert heeft daar de verw zoodanig dik op lag, datmen de schildery by de neus van de grond konde opligten. Dus zietmen ook gesteente en paerlen, op Borstcieraden en Tulbanden door hem zoo verheven geschildert al even of ze geboetseerd waren, door welke wyze van behandelenzyne stukken, zelf in wyden afstand, kragtig uitkomen'.

Hoecker 1916, 272: 'Ginghen de penneelen so niet belasten/ Als nu/ dat men schier blindelijck mach tasten En bevoelen al t' werck aen elcker sijde Want de verwen ligghen wel t'onsen tijde/ Soo oneffen en rouw/men mochtse meenen/ Schier te zijn half rondt/ in gehouwen steenen'. Cf. Van de Wetering 2010, 113. Translation Herman Roodenburg.

Was he thinking of Cornelis van Haarlem's manipulation of paints? Many of the latter's figures take on the appearance of sculptures owing to the handling of the paints. Butterflies appear on their skins as if they have landed on stone. For instance, see The Fall of the Rebel Angels in the Statens Museum for Kunst in Copenhagen, c. 1588 , oil on canvas, $239 \times 307 \mathrm{~cm}$. Cf. Cat. Haarlem 2012.

Hoecker 1916, 278 f.: 'Niet alleen siet ons dinghen uyt den drooghen/ Maer als w'ons best vleesch te schilderen meenen/Soo isset al visch/ oft beelden van steenen'. In regard to Poussin's painting, this negative effect of the colouring is linked to the coldness of disegno by Roger de Piles. See Lichtenstein 1993, 165.

Hoecker 1916, 274-275.

Daniela Bohde demonstrated that this is not simply an art-theoretical topos that Van Mander adopts: 'With the rough texture of the canvas, Titian produces also a tactile effect (...). Especially the impastoed ochres (...) acquire a strongly haptic quality by means of contrast to their nebulous surroundings. You have the impression you can feel their textures'. Bohde 2002, 173 .

57 'Scolpi in pictura propria viva et vera'. Cf. Lightbown 1986, 457, no. 65, quoted after Cat. Berlin \& New York 2011, 38 .

$5^{8}$ Boschini 1966: 'Quando per questo mi son sta Bassan/ Procurete d'aver bona licencia/ D' inzegnochiarme con gran reverencia/ Su quell Altar, per tocar con le man/ Quei colpi, quele machie e quele bote/ Che stimo preciose piere fine,/ Perle, rubini, smeraldi e turchine,/Diamanti che resplende fin la note'. English translation in Sohm 1991, 154 (Boschini 1966, 302).

59 Sohm 1991, 155. Cf. Boschini 1966, 733.

6o Besides Pallucchini's translation, Sohm's study on Boschini has been seminal. However, Sohm interprets Boschini largely in terms of Ferdinand de Saussure's speech act theory, which does not do justice to the power of imagery in the languague of the Venetian author.

61 Sohm 1991, 150. Cf. Boschini 1966, 712. As Sohm mentions on page 139, Boschini underscores on page 373 the fact that 'the Venetians model colour on the canvas with inspired jabs of their fingers'.

62 Von Sandrart 1675, 326. Cf. 2004, 34.

63 For the term franchezza, see: Van Gastel 2013, 169-188. The term is connected with authenticity and originality of the hand and is related to a sketch/bozzetto.

64 Baldinucci 1681,48 and 64 .

65 Jan Nicolaissen points out that 'instead of a smooth, evenly covered surface, the animated brushstroke creates a palpable relief by means 
of the granulated texture produced by the handling'. Nicolaissen 2004, 34.

66 Cf. Van Gastel et al. 2014, 15-47.

67 Wenderholm 2006.

68 Dewey 2004, 125-126. Cf. Chapter VI, 263-264.

69 In Sculpture Herder remarked that sight essentially implied grasping or comprised also a tactile action. (Herder 1778 and Herder 2002). Cf. Wagner 2013, 253-266. Georges Didi-Huberman argues in terms of corporeal painting that 'Deleuze is justifiably in asserting that paint, even if it appears at first to have a purely optical function, has the ability of being modulated in a way to produce a decidedly haptic function. According to Aristotle, we cannot see without the sense of touch. Touching is an intention born of sight'. (Didi-Huberman 2002, 58-59). Max Imdahl also leans in this direction, even if he premises visual effects in painting in the way Fiedler does: 'Paint is not only optically but likewise haptically relevant'. Imdahl 2003, 110. The physical unity of matter as something perceived by the entire body is mentioned by Deleuze and Guattari in Mille Plateaux. There they refer to the hapticity of space, which can be auditory, visual, and tactile. Cf. Largier 2010, 121. On the role of the auditory, see: Trabant 2012, 121-132. In his book Ähnlichkeit und Berührung (L'empreinte, 1997), Didi-Huberman describes the inseparable unity of form and matter (in the tradition of Giovanni Paolo Lomazzo's tutto composto): 'In the field of the visual arts, matter cannot be separated from form, the process not from the result, the tactile not from the visible. Even the problems of perspective depend on a certain tactile experimentation'. (Didi-Huberman 1999b, $5^{2}$ and $5^{8}$ ). Max Imdahl said much the same when he wrote that Courbet 'employed the materiality of the paints to produce the materiality of the objects in his pictures'. Imdahl 2003,110 . This is equally true in the case of De Gelder and the other Rembrandtists. It is widely accepted that Courbet was largely inspired by them as well as by Frans Hals. The way De Gelder and Paudiss modelled paint can be compared to Van Gogh's painting as a physical process: 'Van Gogh inscribed his physical actions into the thick paint, working it with his brush as if it were tractable dough'. Wagner 2002, 30. Paint, when it is applied in this manner, is linked to the body schema and to the sensorimotor and habitual movements of the artist (and this is true for the Rembrandtists as well as Van Gogh). See Gallagher 2006; Krois 2011c, 253-271.

Felfe 2014, 153-175. Van de Roemer succinctly described the pivotal role played by materials in the artistic process: '(...) an artist saw his working materials as substances preserving overt and hidden qualities, or as congregations of tiny corpuscles that move and act according to mathematical regularity'. Van de Roemer 2011, 203. Von Sandrart 1675, 70.

Van de Roemer 2011, 203.

Felfe 2013b, 350-369. See Chapter IV, 154-159.

See Chapter II, 67. Van Hoogstraten 1678, $237 \mathrm{ff}$. Cf. Van de Wetering 2004, 81-87.

Nicolaissen 2004, 37.

Von Sandrart 2008-2012, 86: 'Im Anfang/ als der weise Schöpfer alle Dinge/ was wir mit den Augen sehen/ hervorgebracht/ hat er erstlich/ durch hervorruffung des Liechtes/ das Chaos oder den vermängten Klumpen/ aus welchem alles erschaffen worden/ entdecket. In diesem Chaos, waren damals alle Farben beysammen und durch einander vermänget/ bis sie von einander gesondert worden. Nachdem auch alle Dinge ihre Gestalt bekommen/ werden sie doch durch die Nachtfinsternis wieder verdecket/ und müssen täglich durch das Tagliecht wieder sichtbar werden'.

77 Van Hoogstraten 1678, 237: '(...) of dat het oog in de ruwe schetssen van gevallige voorwerpen eenige vormen uitpikt, gelijk wy aen den haert in het vuer pleegen te doen; of dat de handt, door gewoonte, iets formeert, min noch meer als wanneer wy schrijven; want een goedt schrijver maekt goede letteren, schoon hy 'er niet aen gedenkt, en zijn oog en verstandt schijnen in zijn hand geplaetst te zijn'. Cf. Van de Wetering 2004, 85-86. Chapter II, 67 .

78 Baxandall 1982 has shown how this was the case in German sculpture around 1500 (i.e. the role of chiromancy). Pamela Smith mentions the function that knowledge such as this had in producing pictures. See Smith 2004, 7.

79 Von Sandrart 1925, 301. Cf. Nicolaissen 2004, 39.

$80 \quad$ Busch 2009, 58-59.

81 Van Hoogstraten 1678, 234: 'Geen eygen handeling te betrachten, maer alleen de natuerlijkheyt'. Cat. Leiden 2006, 165 .

82 Van Hoogstraten 1678, 340 ff. Ernst van de Wetering points out the explanations given by 
collectors or specialists of natural objects in the Netherlands. Van de Wetering 1998, 33.

Cat. Amsterdam 1999. On the notion of Kunstkammer in general, see: Bredekamp 1992. Pastoor 1994, 6.

Cat. Amsterdam 1999, 77-78.

Cat. Amsterdam 1999, 60.

Lindeboom 1968, 165-166. Additionally, as Israel has proven, Boerhaave was against Cartesianism and an adherent of Newton. At the same time, he was accused of being a Spinozist. Israel 2001, 478 and 705 .

Van de Wetering 1998, 33; Van de Roemer 2004, 137.

Van de Roemer 2004, 137. In connection with productively exploiting accident in art, Van de Roemer commented on page 200 in Regulating the Arts that 'nature not only should be accomplished'.

Van de Roemer 2004, 136 and 141 ff. Cf.

Baltrusaitis $1983,55^{-88 .}$ Kircher 1665/1678, vol. 2, 37. Quoted after Chang 2003, 45 and 61.

Chang 2003, 35-36.

Boehm 2007b, 77 .

Wessteijn 2008, 111. In this context Pamela Smith noted that Cyriacus of Ancona understood the 'processes of art and those of nature (...) as identical'. Smith 2004, 54 .

\section{Facets of Handling the Paint}

Von Moltke 1994, 82; Cat. Dordrecht/Cologne supplies the examples that art should follow, but also reveals the processes by which this imitation

Van Hoogstraten 1678, 343; Chang 2003, 11 and 16. 1998, 224. The subject matter treated in the painting has long been subject to debate. Tümpel's interpretation has to date found the most widespread acceptance. Cf. Cat. Amsterdam \& Münster 1994, 296.

This impression is independent of the condition of the painting. Gottfried Boehm commented that the visible ground enhances the dynamism of the work, alluding to how Deleuze claimed that the ground ascends to the surface (Geteilte Aufmerksamkeit. Bemerkungen zur ikonischen Differenz, Lecture: 18 June 2013, Humboldt University, Berlin); see the introduction in: Boehm \& Burioni 2012, 11-28.
Cf. Van de Wetering 1998, 23. Therefore, the ' $f$ '. following the signature can be interpreted as meaning faciebat as used in the works of Michelangelo, Titian, and Tintoretto (to name but a few and without considering the regions north of the Alps). Weigel 2006, 257. Anna Tummers emphasizes in regard to artists of the Netherlands that "the addition of " $\mathrm{f}$ " after the artist's name, which is commonly interpreted as an abbreviation of "fecit", also stands for "faciebat". Tummers 2008, 45; Busch 2009, 70-71; Preimesberger 2013, 142-149; Lavin 2013, 150-187; Hegener 2013, 188-231.

The painting was listed in the inventory of the Dresden collection (1722-1728) as 'Ein Heyduckenkopf' (Head of a Haiduk). Cat. Freising 2007, 236.

Cat. Freising 2007, $236 \mathrm{ff}$.

The catalogue of the Paudiss exhibition describes the condition of the painting as 'dissatisfactory' because 'after it disappeared in 1945 it was cut considerably at all its edges, where it was folded double and consequently strongly pressed' (Cat. Freising 2007 , no. 8,238 ). Moreover, 'the entire surface suffered considerably owing to the removal of layers of paint, so that the reddish-brown primer has become visible especially in the areas where the ground tended to be thin'. Hence the damage Paudiss' painting suffered is extensive and makes it now appear unfinished. However, judging by the signature and the primer visible underneath it, it could be ascertained that the work made such an impression already prior to 1945 , which was then reinforced by the subsequent damage.

Cat. Freising 2007, 236.

Cat. Freising 2007, 236. The catalogue (238) asserts that the painting 'goes way beyond a tronie'. However, it does not elucidate this point further.

At this point it is not relevant whether it is really a self-portrait or not. Cat. Freising, $208 \mathrm{ff}$. For Leonardos Sfumato, see: Fehrenbach 2002, $522-544$. On the practice of blurring the contours in the sfumato tradition of Rembrandt's studio as well as its different modes, see: Weststeijn 2009, 423-427.

For instance, the signed picture: Puttertje (Goldfinch), 1654, oil on panel, $33.5 \times 22.8 \mathrm{~cm}$, Mauritshuis, The Hague. Cf. Cat. Schwering \& The Hague 2005, 142. 
Bauer-Empl 2007, 175 .

Bauer-Empl 2007, 174. This impression is enhanced by the condition of the work. Cf. Chapter v, 196-199.

Cat. Freising 2007, 213, adopted Seifertova's view of 'the dissolution of the contours leading to an overall "vibrant", flimmering atmosphere', who states on (202) that his 'manner of painting produces a blurred effect'. Seifertová 1977, 224-241.

Cf. Krempel 2005, 126. Van de Wetering 2004, 21: '(...) where the ground is visible, it always appears to be a light yellowish-brown colour'. The same can be claimed for Fabritius' paintings as well as those by Paudiss and De Gelder. Busch 2009, 67 and 70. See Cat. New York 2016. Houbraken 1753, vol. 1, 259: 'En in zulk doen was hy niet te verzetten, nemende tot verantwoording dat een stuk voldaan is als de meester zyn voornemen daar in bereikt heeft, zoo ver dat hy om eene enkele parel kragt te doen hebben, een schoone Kleopatra zou hebben overtaant'. Cf. Van de Wetering 1991, 21. Chapter III, 115. Houbraken 1753, vol. 1, 259: 'En dus ging het ook met zyne schilderyen, waar van ik 'er gezien heb, daar dingen ten uitersten in uitgevoert waren, en de rest als met een ruwe teerkwast zonder agt op teekenen te geven was aangesmeert'.

On Rembrandt's sketchy and rapid execution in this context, see: Courtright 1996, 485-510.

Houbraken 1753, vol. 1, 259.

Houbraken 1753, vol. 1, 258-259: 'Maar een ding is te beklagen dat hy zoo schigtig tot veranderingen, of tot wat anders gedreven, vele dingen maar ten halven op gemaakt heeft, zoo in zyne schilderyen, als nog meer in zyn geetste printkonst, daar het opgemaakte ons een denkbeeld geeft van al 't fraais dat wy van zyne hand gehad zouden hebben, ingevallen hy yder ding naar mate van het beginsel voltooit hadde, als inzonderheid aan de zoo genaamde hondern guldens print en andere te zien is, waar omtrent wy over de wyze van behandelinge moeten verbaast staan; om dat wy niet konnen begrypen hoe hy het dus heeft weten uit te voeren op een eerst gemaakte ruwe schets, gelyk blykt dat hy gedaan heeft aan het pourtretje van Lutma dat men eerst in ruwe schets, daar na met een agtergrond en eindelyk uitvoerig in print ziet'.

Van Hoogstraten must have learned the following opinion about sketchiness directly from
Rembrandt: Van Hoogstraten 1678, 27: 'Deeze manier van in 't gros te schetssen, is by de meeste op een onbedwonge wijze in 't gebruik (...) maer wat verder het ruw schetssen belangt, het is de eerste grontvest van 't wel teykenen (...)'. For an English translation, see: Van de Wetering 2010, 33: 'This way of sketching the whole is mainly used in an unforced manner (...) [but] what further concerns the rough sketching, it is the first foundation of good draughtsmanship (...)'. See the following section.

25 The exhibition Rembrandt gespiegeld (Rembrandt Mirrored) at the Rembrandthuis (20092010) made this clear. Cf. Busch 2011b, 281.

$26 \quad$ Houbraken 1753, vol. 1, 259.

27 Weststeijn examines the relationship between Spinoza and Van Hoogstraten without referring to this passage: Weststeijn 2008, $33^{-}-35^{1}$; on the relationship between Spinoza and Rembrandt: Valentiner 1957 and Panofsky 1973, 75-108.

28 Spinoza 2003, Part IV, Preface.

29 Spinoza 2003, unpaginated.

$30 \quad$ Spinoza 2003, unpaginated.

31 Von Sandrart 1675, I, Book 3 (Malerei), 103.

32 The person executing the work can of course simultaneously be a beholder. Cf. Chapter v, 225.

33 Van de Wetering 1991, 21; Van Hoogstraten 1678, 27 and 291.

34 Van Hoogstraten 1678, 321. Cited in Weststeijn 2008, 239: 'Daerom hebben groote meesters ook wel dingen, die in 't eerste aenleggen een gelukkige welstant hadden, onopgemaekt gelaten, van vreeze dat zy die zouden bederven. Zoo kann 't ook gebeuren dat de grondverwe uwes doeks of paneels in 't koloreeren te pas komt, en met eenige duwkens geholpen, uwen arbeyt verlicht'. Van de Wetering 1991, 21.

36 For instance, see: Sohm 2007, as well as the corresponding remarks on both artists, for example in Van Hoogstraten 1678, 242. What Houbraken says about Rembrandt is also relevant here: 'Liever dat stuk onvoldaan wilde aan zig houden, dan hun ten gevallen de kwast 'er op zetten, gelyk ook geschiedde; waarom het gemelde stuk ook naderhand, tot een afschutting gedient heeft voor zyne Leerlingen. (...) En ik heb opgemerkt dat hy in zyn vroegen tyd wel meer gedult gehad heeft om zyne konststukken uitvoerig te bewerken dan daarna' (Houbraken 1753, vol. 1, 26o). Cf. the exhibition on late Rembrandt: Cat. London \& Amsterdam 2016. 
Sohm 1991, 32.

Gilbert 2003, 57. This approach in reception aesthetics can be found later in Gombrich's dictum of the 'beholder's share' or in Kemp's study 'Der Betrachter ist im Bild'. Cf. Gombrich 196o, 181-241, and Kemp 1985. As Sohm ascertained, Boschini too described the active role of viewers in 'completing the unfinished': 'Boschini's viewer finds an "unfinished" image which is only completed in the viewer's imagination. Hence the painting is a stimulus for the imagination and can be finished only with the active participation of the viewer'. Sohm 1991, 147.

Warnke 1993, 61-69. Warnke speaks about the negative side of the imagination that does not perceive the given reality. Cf. Gamboni 2002, 17 . Vasari 1998, 503-504. Cf. Bohde 2002, 27. Hoecker 1916, 276-277: 'Want d'Ouders wercken en wilden niet ronden'.

Vasari 2009, 56. Cf. Bredekamp 2010c, 17. On this problem in sculpture, see: Bredekamp 2009, 203-210.

Cf. Warnke 1977, 5-28.

Reynolds 1997, 202.

Frank 2008, 217-218. Cf. Chapter II, 71.

Reynolds 1997, 164.

Cited after Atkins 2012, 61.

Cf. Suthor 2012, $225 \mathrm{ff}$;; and passages in Suthor 2014. See the critique by Koos 2017 about Suthor's understanding of the notion of dood verf.

Cf. the last part of this Chapter.

Atkins 2012, 209. As a side note, Hals and Van Dyck feature constantly in art literature as rivals (see Houbraken's biography of Frans Hals). In their painting, each adapted elements from the other. Cf. Cat. Haarlem 2013.

Compare Stückelberger 1996. Willem Bürger

(Théophile Thoré), who discovered Vermeer and was a great admirer of Courbet, lauded the unfinished quality of Frans Hals' brushstrokes. See Bürger 1870, 414. Cf. Atkins 2012, 213. On Courbet's play with the non finito, see: Krüger 2012, 109-127.

Busch 2002, 31.

Vincent van Gogh to Theo van Gogh, 13 October 1885. Cf. Bikker 2013, 7 .

Gludovatz 2011. See her Chapter vi. Cf. Busch 2004. The unfinished in painting is equated with the unaccomplished goals of the German Revolutions of $1848-49$. This is reminiscent of
Gerard de Lairesse's classifying the middle class as an unfinished project integral to the modern manner. Atkins 2012, 199. Cf. De Vries 2004, 95: '(...) lack of diligence (...), lack of detail in the objects represented'. Busch 2012, 192: 'Der zur Anschauung gebrachte atmosphärische Moment wird nicht etwa auf Dauer gestellt, vielmehr durch die Form seiner unvollendeten Erscheinung verlebendigt'.

Conrad 1959, 35; Frey 1959, 91-116; Cat. New York 2016.

In regard to Cézanne, the French critic Gustave Geffroy summed up the situation as follows: 'Art always contains an element of unfinished [in achievement] for the life that it reproduces is in constant transformation'. Geffroy 1903, 376. Quoted after Simms 1999, 227.

Althusser 2006, 174.

Painted around 1722 (Amsterdam, Rijksmuseum). Houbraken 1753, vol. 3, 207-208: 'Somwylen smeert hy ook de verf wel, als hy by voorbeeld een franje of borduursel op eenig kleed wil schilderen, met een breet tempermes, op het paneel of doek, en krabt de gedaante van het borduursel, of de draden der franje daar uit met zyn penceelstok, zonderende geene wyzen uit, als zy maar tot zyn oogmerk behulpig zyn; en ' $t$ is te verwonderen hoe natuurlyk en kragtig zulk doen somwylen zig in afstant vertoont'. This technique is described by Houbraken in the biography of the artist. Van de Wetering comprehends De Gelder's scratching as a process that is experienced by a number of senses: 'The scraping noise that the flat knife makes on the canvas, the rhythmic scratching of the end of the brush must have often broken the silence'. See Van de Wetering 1998, 19. Several additional reflections on this topic can be found in: Hadjinicolaou 2013. Cf. Chapter v, 221-222.

2 Ernst van de Wetering made a fundamental contribution to the topic of accident in De Gelder's art and pointed out similarities as well as significant differences to Rembrandt, especially in regard to technique. Van de Wetering 1998, 21. Van de Wetering 2004, 222.

3 Rembrandt's Jewish Bride is an example with scratching similar to De Gelder's. However, it does not have the same extremely radical quality. See Suthor 2010, 247. The technique of scratching can be discerned in Konrad Witz's rendering of 
the wall behind the manger in his Nativity panel (c. 1445) now at the Kunstmuseum Basel.

65 Van de Wetering 1998, 32.

66 Van de Wetering 1998, 32.

67 Boschini 1966, 711-712. Cf. Von Rosen 2001, 416-417.

68 Pacheco 1990, 483: ‘(...) Dominico Greco traxese sus pinturas muchas veces a la mano, y las retocase una y otra vez, para dexar los colores distintos y desunidos y dar aquellos crueles borrones para afectar valentia (...)'. Cf. Hadjinicolaou 2019. Van de Wetering 1998, 35 .

Van de Wetering 1998, 25 .

Sohm 1991, 16.

Hoecker 1916, 224-229: 'Seer verlegen vondt hem eens een bysonder Schilder/ na grooten Valery beschrijven/ Die had een Peert gemaect seer schoon te wonder/ Welck quam uyt den arbeyd/ en als hy onder Ander dingen wouw/ tot zijns Consts beclijven/ Maken dat schuym te mondt uyt quame drijven/ Desen constighen werckman heeft al langhen Vergeefschen tijdt en moeyt daer aen gehangen. Zijn constich werck en cond' hy niet gebrengen Ten Eynde/ noch comen tot zijn vermeten/ Hoe dat hy proefde/ dus met soo gheringhen/ Onweerdighen/ oft ongheachten dinghen Wesende ghequelt/ het heeft hem ghespeten/ En heeft om verderven daer op ghesmeten De sponsy/ daet hy zijn verwen me vaechde/ En de saecke gheviel soo 't hem behaechde. Want de spattingh der sponsy is ghebleve Aen sijn Peerts mont hangend/ wt quaden spele/ Ghelijck natuerlijck schuym/ dus is becleven Zijn vorneem en werck/ 't geluck toegeschreven/ En niet zijn Conste/ maer't is even vele In summa/men bevindt met wat een zele En yver sy van oudts/ so sy best mochten/ All' eyghenschappen uyt te beelden sochten. Te Room oock in de sale Constantini, Daer is dat schuymen uytghebeeldt ten rechten Protogenes, nae 't ghetuygenis Plinij, Conde niet ghemaken na zijn opiny't Schuym aen eenen hont/ en ging om so slechten Ondoenlijck dingen oock zijn werck bevechten Metter sponsy/ghelijck gheseydt is boven/ Doe stond 't oock so wel/ dat yeder most loven. Want eerst en stonde dit schuym niet natuerlijck/ Seyt Plinius, maer te seer afghescheyden Van 't oprecht in 't leven/ maer scheen figuerlijck Geschildert met vlijt/ t'welcke by wilde puerlijck Wt den mondt doen vloeyen met veel arbeyden Nealcas deed oock een Ionghen leyden/ Oft houden een Peert/ en troetelen mede/ Daer zijn sponsy oock dus mirakel dede. Dus mogen wy ooc/alst past/ op het schuymen Der Peerden letten/met neerstich volheerden'.

Hoecker 1916, 226-227.

Hoecker 1916, 228-29: 'Hoe een dingen gemaeckt is/'t zy met duymen/Met sponsy/oft anders buyten costuymen/'t Is al goet wat wel staet/ ick houdt in weerden'.

Van Mander 1906, 196-197: 'Het zyn doch eenighe, die om hun behendicheydt te toonen, wel derghelijcke onghewoon dingen bestaen en doen: Eenighe schieten met 't Roer op den rugghe, oft verkeert, en raken daer sy op micken. Ick laet staen, dat eenighe loopen op touwen, daer de aerde nochtans bequamer toe is'. Cf. Suthor 2010, 245. For Ketel see Chapman 2009.

76 Hoecker, 194. Van Mander goes a step further comparing Ketel's habits to the appetites of pregnant ladies in wanting to eat strange raw or uncooked foods. Besides being critical to an extent between the fijn and rough manner, it cannot be said whether the qualities of rawness or not being processed also encompass the spontaneous and unlaboured.

77 Carol Pottasch's (Senior Conservator, Mauritshuis) manuscript on the processes involved in restoring Boerhaave's portrait justifies the assumption that these areas were shaped by the artist using his fingers. See Lehmann 2018.

78 Pliny the Elder 1994, 92 ff.: 'Displicebat autem ars ipsa: nec minuit poterat et videbatur nimia ac longius a veritate discedere, spumaque pingi, non ex ore nasci. Anxio animi cruciatu, cum in pictura verum esse, non verisimile vellet, absterserat saepius mutaveratque penicillum, nullo modo sibi adprobans. Postremo iratus arati, quod intellegeretur, spongeam inpegit inviso loco tabulae. Et illa reposuit ablatos colores qualiter cura optaverat, fecitque in picture fortuna naturam. Hoc exemplo eius similis et Nealcen successus spumae equi similiter spongea inpacta secutus dicitur, cum pingeret poppyzonta retinentem eum. Ita Protogenes monstravit et fortunam'.

79 Dion Chrisostomos wrote the same in a later narrative and ascribed the anecdote to Apelles. However, in his rendering of it there is a decisive difference that is especially relevant to this

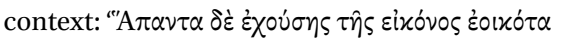




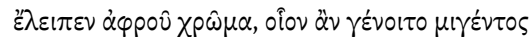

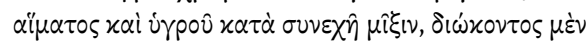

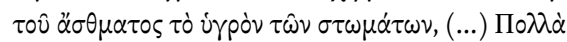

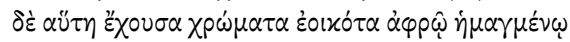

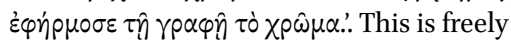
translated as: 'Only the colour of the foam was missing, that is, the colour of a mixture of blood and saliva produced by the body as it breathes (...). And because the sponge had many different coloured paints on it, which mixed together resembled the bloody foam on the animal's mouth, the colour was in keeping with the painting'. According to Chrysostomos, accident perfected that which could not be realized by the means of art. Cf. Pliny the Elder 1994, 385 .
Neumaier 2010, 165, 171, 175; Butcher 1951, 180. This quote underscores how the variability of matter is closely enmeshed with accident.

Janson 1961, 254-266.

Alberti 2013, 9 .

Cf. Gombrich 2004, 154-161.

Alberti 1970, 66.

Leonardo 1956, 5 o.

Bredekamp 2012a, 110-112.

Leonardo 1956, 51 .

Janson 1961, 262. Janson entertains the idea of whether Leonardo inspired Botticelli's chance pictures. Bätschmann is of the opinion that the discovery of natural images happened by accident, contradicting Janson's theory that considers natural images as chance images. See Alberti 2000, 31. Dario Gamboni wonders whether it would be better to speak of potential images as 'chance images'. See Gamboni 2002. Cf. Damisch 2013, 53-6o.

Leonardo 1956, 59 .

Suthor 2010, 243.

Another example in this context is Tintoretto's painting. However, he is criticized by Vasari because chance directs the colpi of his brush, producing 'sketches so rough that the brushstrokes may seem done more by chance and vehemence than with judgment and design' ('che si veggiono i colpi de' pennegli fatti dal caso e dalla fierezza, più tosto che dal disegno e dal giudizio'). Quoted after Weigel 2006, 233. Cf. Von Rosen 2001, 327.

Lucretius 2008a 'Nam tibi de summa caeli ratione deumque disserere incipiam et rerum primordia pandam, unde omnis natura creet res, auctet alatque quove eadem rursum natura perempta resolvat (...) esse ea quae rerum simulacra vocamus; quae quasi membranae summo de corpore rerum dereptae volitant ultroque citroque per auras, atque eadem nobis vigilantibus obvia mentes terrificant atque in somnis (...)'. Cf. Lucretius 2008b, 10-11 and 256-257. On Lucretius' theory of painting, see: Bredekamp 2010b, 319: 'Die fliegenden Hüllen von Licht und Farbe schwirren ähnlich wie Geruch, Rauch und Dampf durch den Raum, wobei sie sich berühren und bei Kontakt mit Materie auch verformen können. Dies bewirkt, daß sie ,verschwommen den Dingen' entströmen. Hierin besteht die Diffusität des lebensspendenden sfumato der Malerei' (Cf. Bredekamp 2018, 276: 'The flying sheaths of light and colour flitted through the air, much in the way of sounds, smoke and steam, on occasion merging and, when coming into contact with matter, also altering their shapes. This, indeed, produced the illusion that they were "hazily" streaming out of things. it is in this that the diffuse quality of the enlivening sfumato in Leonardo's own paintings consists.)

Cf. Greenblatt 2011, 5 . Greenblatt 2011, 188-189.

Wolf 1999, 62-63; Gamboni 2006, 63 ff.; Bredekamp 2010b, 173-178.

96 Van Hoogstraten 1678, 237 ff. Cf. van de Wetering 2004, 81-87; Volmert 2013, 16o f. For Jan van Goyen's landscapes, see: Cat. Leiden 1996, 12. Powell 2017. Van Mander already reported how such rivalry was related to speed of execution, which appears to allude to Van Goyen's painting practices and the competition between the two artists. Cf. Atkins 2012, 118. The other references to rivalry that are significant in the context of handeling were pointed out in Chapters II and III. They will also be addressed in Chapter vi, with Van Hoogstraten's narrative playing a pivotal role in understanding the painting practices of the Rembrandtists. Cf. Roskill 1997, 78. Cat. Leiden \& Kassel 2006, 47-53.

98 The passage was quoted in Chapter II (67). In the context here, it acquires a different meaning. Van Hoogstraten 1678, 237-238. Cf. Weststeijn 2008, 251: '(...) en in 't kort zijn oog, als op het uitzien van gedaentens, die in een Chaos van verwen verborgen laegen, afgerecht, stierde zijn hand en verstandt op een vaerdige wijs, zoo 
datmen een volmaekte Schildery zag, eermen recht merken kon, wat hy voor hadt'. 'Un Caos (...) de colori indistinti e miscugli di confusione'. Boschini 1966, 725. Quoted after Weststeijn 2008, 238. Van Hoogstraten 1678, 233. '(...) daer verliest den Schilder bynae al wat hy begreepen heeft, eer hy't met verwen kan uitdrukken. Protogenes en Neacles vonden zich verleegen, hoe grooten vlijt zy ook aenwenden, in het schuim, d'eerste van een hond, en de tweede van een paert, uit te beelden, ja geraekten in zoo flechten zaek buiten gedult, bewerpende haer werk, als wanhopende, met de sponsiën; en schoon de besmette sponsiën 't begeerde te weeg brachten, en hun dieren zeer natuerlijk deeden schuimbekken, zoo bleek hier uit, dat hun oordeel fix genoeg, maer hune handt te traeg was. Doch, gelijk Seneka zegt, zoo is dit het eenige, dat den Schilders by geval gebeurt ist, in het uitbeelden van iet natuerlijx'. Translation Herman Roodenburg. Van Hoogstraten, 236-237. Translation from Van de Wetering 2010, 119: 'Een goet konstenaer, zegt Seneka, handelt zijn gereetschap behendich, of met een zonderling gemak. (...) Moeilijk gedaen, moeilijk om te zien, zegtmen'. See the same quote in Chapter III (134). Van Hoogstraten 1678, 237. Van de Wetering 2004, $85-86$.

103 Weststeijn 2008, 256-257.

104 Van den Vondel 1937, 32-33: "t wild geval/ Het t'zamenrunnen der ondeelbre vezelingen/ En stoffe'. He did believe that 'Natuur kan zonder hand en verf geen landschap schilderen/ Wat kan dit wild geval? Niet anders dan verwilderen'. Cited in Weststeijn 2008, 256. One wonders if this attitude relates to Vondel's conversion to Catholicism.

Cf. Emmens 1979, 168-169.

Von Sandrart 1675, I, 6o, unter: http://ta.sandrart. net/edition/text/view/147\#tapagehead [22 Jan. 2014].

Bert van de Roemer puts this problem in a nutshell: 'As mechanistic natural philosophy tried to deny the existence of chance in nature, writers on art that honoured the classicist principles tried to eliminate chance from the process of painting'. See Van de Roemer: 2011, $200 \mathrm{ff}$.

108 Cf. Leonhard 2008, 42 and 47.

109 This process is analogous to clinamen: 'Clinamen is the "smallest" infinitisimal swerve (...). It makes an atom deviate from its vertical fall into a void so that its parallel path only changes ever so slightly, causing it to collide with a neighbouring atom. This leads to collision after collision - progressively - and ultimately the birth of a world, that is, an atomic aggregate, which the initial deviation first created by the first collision initiating a chain reaction'. (Althusser 2010, 22-23) Cf. Leonhard 2008, 51. On the term clinamen, see: Greenblatt 2011, 188-189; and Bredekamp 2012b, 88.

110 Cicero 1992, Divinatio, 250-251; http://data. perseus.org/citations/urn:cts:latiniLit:phio474. phio53.perseus-eng1:1.23 (accessed 16 Dec. 2017). Cf. Cat. Vienna 2003, 40. Cicero 1991, 30-31: '(...) adspersa temere pigmenta in tabula oris liniamenta efficere possunt; num etiam Veneris Coae pulchritudinem effici posse adspersione fortuita putas? (...) fingebat Carneades in Chiorum lapicidinis saxo diffisso caput exstitisse Panisci; credo, aliquam non dissimilem figuram, sed certe non talem, ut eam factam a Scopa diceres. sic enim se profecto res habet, ut numquam perfecte veritatem casus imitetur'.

111 De Vries 2004, 95.

112 De Vries 2004, 82. De Gelder opposes De Lairesse's recommending the 'sound distribution of the colours (...) as graces of painting'.

113 Cf. Chapter II, 98-101.

114 Cozens investigated and experimented with accident from 1759 to 1785 .

115 Busch 1993, 346.

116 Cozens 1785/6, 8-9. Quoted after Busch 1995, 209 and 220; Stückelberger 2006, 117. See Chapter II, 70.

117 Cf. Cat. Frankfurt 2007, 125 ff.: 'One morning, in the year 1807 perhaps, Turner encouraged three children to dip their hands into water colours of red, yellow, and blue and then play around with them on a sheet of paper. Based on the smudges that were created by the children he painted a landscape. The anecdote was first documented in 1879 and articulates a characteristic principle of Turner's art: using blots and chance'. (The anecdote is mentioned on page 190 in Hamerton 1879).

118 On the rivalry between the two, see: Busch 2009, 190-209. John Constable's cloud pictures are the objects of Cozen's reflections on autopoiesis and, therefore, also on how accident is related to his 'blot-spot method'; on this topic, see: Busch 1993, 
350. Gainsborough's landscapes are mentioned in this context.

Cat. Frankfurt 2007, 317; Bredekamp 2010b, 267-268. Reports of similar experiments with chance in art exist in Eastern Asia (Focillon 1989, 175-178ff. Focillon mentions the example Hokusai). As early as around 840 , the Chinese painter Wang laid the cornerstone (in Chu Ching-hsuan's compendium of the arts of China) for a Cornelis Ketel or De Gelder by painting with his hands and feet. In this way, with the aid of accident, he created natural objects and landscapes, and later inspired Jackson Pollock. Bredekamp 201ob, 270. For Pollock, see: Lachman 1992, 501.

Quoted after Cat. Vienna 2003, 28. Cf. Sylvester 1999, 92.

Weltzien concludes, in the spirit of Pliny, that 'in painting accident created truth to nature'. Weltzien 2011, 278. The role of chance in Rembrandt's art is seen in a similar light: '(...) he gave increasing room for chance to play a role, presumably on the assumption that this encourages the beholder to see in it a natural, concrete reality'. Van de Wetering 2010, 140.

For instance, see Christ Crowned with Thorns or The Burial of Christ. Bassano's impact was observed by Lilienfeld 1914, 119. Cf. Hadjinicolaou 2018a.

Weyerman 1729/69, vol. 3, 43: 'Een wonderbaare verkiezing van lichten en schaduwen'.

Cat. Freising 2007, 219-222. See Bredekamp 2010b. Cf. J. Dewey 2005, 208-209. On the notion of agency, see: Gell 1998; Bredekamp 2010; Van Eck 2015, Bredekamp 2018.

Cf. Krieger 2006, 91-112.

For the term liveliness, see: Fehrenbach 2003a, 151-170; and Fehrenbach 2003b, 222-227.

Fehrenbach 2010b, 34 .

Cf. Chapter vi.

Cf. Cranston 2010, 6.

Quoted after van Gastel 2013, 157-158. Cf.

Malvasia 1841, vol. 1, 362-363: 'Quindi rivolgendosi alcuno a considerate in generale la dilicatezza di tutte le carni (...) mentre dall'una parte ed il candore, ed i lumi, che spuntano dalle sommitá delle membra, in quelle n'osserverá, gli pareranno al sicuro, come sodi alabastri, ed avorii; ma s'egli riguardera dall'altra la facilitá, e morbidezza delle varie piegature, e la soavitá dell'ombre, leggiermente sparse per le picciole

vallette, che in diversi parti si formano; gli verrá per certo alla mente la tenerezza delle giuncate: e tra l'uno e l'altro ingannatone il senso e la vista, ed istupidito egli dello accoppiamento di si differenti qualitá, talora di sperimentare ció ch'elle sieno in toccandole, averá desiderio; talora nell'avvicinarsele dubiterá di non turbare quell dolce sonno'.

Houbraken 1753, vol. 1, 262 and 267-268: 'Van deze meening was ook onze groote meester Rembrant, stellende zig ten grondwet, enkele naarvolging van de natuur, en alles wat daar buiten gedaan wird was by hem verdagt. (...) vermoegte zig met het leven te volgen, zoo als het hem voorkwam, zonder eenige keur daar ontrent te maken. (...) Ten minsten zyne [natuur], die geen regels, nog geen reden Van evenmatigheid gedoogde in 's menschen leden'. In this Rembrandt is close to Albrecht Dürer. See Van de Wetering 2010, 137. '(...) dat met uit het leven, het leven leert kennen'.

De Bisschop 1671. English translation from Sluijter 2006, 197-198: 'Datmen derhalven het leven most volgen sonder onderscheit en soo gelijck het sich meest en over al vertoonden'.

134 Houbraken 1753, vol. 1, 266. However, Houbraken distances himself from this principle, which Rembrandt adhered to, and reveals his critical stance while simultaneously acknowledging that the artists who painted after nature were the best (263): 'Wy willen graag toestemmen dat naar't leven te schilderen nootzakelyk en goed is, maar dat dit niet tot zoo een algemeenen grondregel kan gebragt worden, dat het leven enkel te volgen de eenige weg zoude wezen om volmaakt in de Konst te worden; want dan zoude nootzakelyk moeten volgen, dat de genen die zig meest gewenden naar 't leven te schilderen de beste meesters in de Konst waren, dat niet algemeen doorgaat, maar in tegendeel ontrent velen onwaar bevonden word'.

Van Mander 1604, fol. 191r. Cited in Van de Wetering 2010, 135: 'Dan zijn segghen is dat alle dinghen niet dan Bagatelli, kinderwerck oft bueselinghen zijn t'zy wat oft van wien gheschildert soo sy niet nae t'leven ghedaen en gheschildert en zijn en datter niet goet oft beter en can wesen dan de Natuere te volghen. Alsoo dat hy niet eenen enckelen treck en doet oft hy en sittet vlack nae t'leven en copieert end'en schildert'. 
136 Houbraken 1753, vol. 1, 270. '(...) alles staat zoo natuurlyk afgebeeld dat men uit de pentrekken lezen kann wat elk zeggen will'.

Houbraken 1753, vol. 3, 207-208: '(...) en 't is te verwonderen hoe natuurlyk en kragtig zulk doen somwylen zig in aftstant vertoont'.

138 See Chapter vi, 246.

139 Houbraken 1753, vol. 1, 269: 'Dus zietmen ook gesteente en paerlen, op Borstcieraden en Tulbanden door hem zoo verheven geschildert al even of ze geboetseerd waren, door welke wyze van behandelen zyne stukken, zelf in wyden afstand, kragtig uitkomen'.

140 Houbraken 1753, vol. 1, 269: '(...) 't geen zoo konstig en kragtig uitgewerkt was, dat het kragtigste penceelwerk van van Dyk, en Rubbens daar by niet kon halen, ja het hoofd scheen uit het stuk te steken, en de aanschouwers aan te spreken'. Translation Herman Roodenburg.

141 Weyerman 1729/69, vol. 3, 43: 'Dat konterfytsel was gelyk aan het leeven'.

142 Weyerman 1729/69, vol. 3, 43 .

143 See Excerpts: Hofstede de Groot Fiches, RKD (Rijksbureau voor Kunsthistorische Documentatie).

144 'Zeer krachtig en fraay geschildert'. Auction in Amsterdam 14 August 1771. In a French auction where another one of his paintings came under the hammer on 1 October 1810 the word krachtig was translated as 'd'une forte couleur et d'un effet vrais' [author's emphasis]. Further examples of descriptions of De Gelder's paintings using the adjective krachtig are: on 25 August 1773, in Amsterdam in the phrase 'zeer krachtig op doek geschildert'; on 25 April 1775, also in Amsterdam, 'krachtig en schoon in de manier van Rembrandt geschildert'; on 7 October 1783, in The Hague, 'fraay en krachtig, in de manier van Rembrandt geschildert'; on 30 August, 1797, 'krachtige uitwerking', on 11 June 1801, in Amsterdam, 'krachtig, fix en meesterlyk behandeld', and, at the same place, on 30 May 1821, 'krachtig en meesterlijk geschildert'.

145 Dresden Hauptstaatsarchiv. A letter by Paudiss to Johann Georg II, the Elector of Saxony, dated 6 February 166o. Cat. Freising 2007, 17: '(...) jägerey (als einem dem höchlöblichsten churhause Sachsen fast gancz eigenen, und nirgents so hochgebrachten höchstrühmlichen exercitio) mit sonderbahren doch ungerühmbten fleisse, so gut ich es durch gottes gnade erlernet und zwar alles nach dem leben [emphasis of the author] kunstmässig verferttigen (...)'. This reminds one of Van Eyck's signature 'als ich can' (as I can).

146 Cf. Bakker 2011, 37-52; Felfe 2013a, 165-195.

147 Van Hoogstraten 1678, 294: '(...) zoo moet een konstoeffenaer zich tot de levende natuur keeren'.

148 On the relation between Leonardo - van Hoogstraten concerning the question nature-art see Weststeijn 2009, 420-423.

149 Hoecker 1916, 280: "in 't leven 'T patron".

150 Keazor 2002, 13; Sluijter 2006, 203.

151 Van Hoogstraten 1678, 226: '(...) en in 't breeken der verwen, in 't koloreeren, de natuer zien nae te komen'.

$15^{2}$ As Van de Wetering palbably describes, this idea has a key significance for Sandrart: 'as Sandrart explained, naturalness could only be achieved through the use of broken colours for otherwise the colours (of the costumes) in paintings look more like the "boxes of pigments in the shop or strips of textile from the cloth-dyers"'. Van de Wetering 2010, 110.

153 Cited in Van de Wetering 2010, 110; Van Hoogstraten 1678, 225: '(...) waer over veele als wanhoopende zich alleen een wijze van koloreeren gewenden, om haere Teykeningen in Schildery te brengen; zonder op eenige natuerlijkheden te letten, als of de kolorijt hun niet aenginge'.

154 Van Hoogstraten 1678, 36: 'Want als den roemtuchtigen Titiaen tot Romen in 't Belvideer gekomen was, vertoonde hy aen Michel Agnolo een naekte Danae van zijn konst, welke Agnolo tegens Vasary, dieze met hem gezien hadde, ten aenzien van't koloreeren en schilderen zeer prees; maer hy zeyde, dat het schade was, dat de Veneetsche Schilders, in hun begin, niet wel en leerden teykenen: want, vervolgde hy, zoo dezen man zoo wel door de Teykenkonst geholpen ware, als hy in 't navolgen der Natuer met de verwen is, zijn werk zoude overbeterlijk zijn'.

155 Van Hoogstraten 1678, 216: 'De Venetiaenen, om wel en natuerlijk te koloreeren'.

156 Van Hoogstraten 1678, 36: 'En dezen wech zal de jeugt voor eerst alderdienstichst zijn, datmen zich gewenne de dingen, eeven alsze zijn, na te bootsen, om met der tijdt, tot de kennis der dingen geraekt zijnde, de schoonste met oordeel te verkiezen'. 
Taylor 2013, 97; Van Hoogstraten 1678, 176: '(...) zijnde zoo schilderachtich van gedachten, zoo zwierich van sprong, en zoo krachtich, dat, nae zommiger gevoelen, al d'andere stukken daer als kaerteblaren nevens staen'.

158 De Lairesse 1740, vol. 1, 323-324. Quoted after Slive 1988, 163; Taylor 2011, 65 .

159 Cf. similarly Tummers 2011, no. 47, 275: 'A perfect illusion of lifelikeness is often celebrated as one of the most important goals of the art of painting, yet a perfect illusion cannot be appreciated if the viewer does not realize that he or she is looking at a picture. In other words, a perfect illusion requires an awareness of the deception'.

Fehrenbach sums up this vibrancy as being somewhere between 'the delicate distance between fact and dead material on the one hand and demonic, divine, alchemistic, mechanistic ensoulment on the other'. Fehrenbach 2005, 3 . This is in agreement with Warburg's dictum of 'you live and do not harm me'.

161 Vos 1726, vol. 1, 356: 'De levendige geest verdooft de doode verve'. Cf. Weber 1991, 144.

162 Vos 1726, vol. 1, 10

163 Vos 1726, vol. 1, 126: 't Penseel, beroemt door geestigheën Moet nimmer teegens 't leeven stryen'.

164 Camphuysen 1681, 195: 'Nochtans leeft schilderey/en ziet haar ziender aan; (...) die niet uyt vleesch en bloed/maar gomm' en aarde zijn'. Quoted after Weber 1991, 66-67. Christopher Paudiss also used red macchie. Cf. Cat. Freising, 180: 'Especially red dabs of colour like the triangular shape next to the boy in the Cleansing of the Temple lend rich accents of colour (...)'.

Moltke 1994, 114.

Boschini 1966, 711-712. Cf. Sohm 1999, 107. Land 2012, 23. The fluidity of paint and its potential was treated in the previous section on chance. Cf. Fricke 2013, 53-69.

Busch 2009, 140-141. Van Mander, too, describes how without preliminary drawing Titian 'painted from life'; Cf. Sluijter 2006, 201. On the missing signs of underdrawing as well as the role of pentimenti in Paudiss' paintings, see: cat. Freising 2007, 171.

$170 \quad$ Fehrenbach 2010b, 34.

171 Cf. Chapter vi, 264-266.

172 Cat. Freising, 197.

173 Busch 2009, 128.
Busch 2009, 128. In Van Hoogstraten's eyes, tonal gradations instead of a 'linear rendering of space' are central to Rembrandt's method, as emphasized by Weststeijn, and also linked to the notion of ronding. Weststeijn 2009, 428-429.

De Lairesse 1740, vol. 1, 325: 'zo ten opzichte van zyne natuurlykheid, als ook zyne uitsteekende kragt. (...) was'er ooit een Schilder die de natuur in kracht van coloriet zo na kwam, door zyne schoone lichten (...) En is zulks niet genoeg om de geheele waereld te verlokken (...)?' Cited in Weststeijn 2008, 227.

Taylor 1992, 223.

Vasari 1966, vol. 1, 124-125 and 128. Quoted after Taylor 1992, 223: 'A painting with una dolcissima e delicatissima unione had its lights and shadows blended by the brush and not left unmixed in thick swathes of impasto, or as Vasari put it, carichi di corpo'.

178 Sohm 1991, 11.

179 Pino 1548/Barocchi 1960, vol. 1, 119. Quoted after Sohm 1991, 11: '(...) do not reproduce it [nature] but only vaguely suggest the effect of life'. Sohm 1991, 166.

181 Cf. Sluijter 2006, 212. See on the notion of Kraft Fehrenbach et al. 2018.

182 For this aspect, see: Chapter II, third part.

183 Goeree 1670, 128: 'De Houdinge is een van de nootwendigste dingen die in een Teikening of Schilderye moet waargenomen worden; om dat zy ons het selve gevoel aan het oog doet krijgen, dat wy in't beschouwen van de natuurlijke dingen genieten. Want wanneer de Houdinge in de nagebootste beeldnissen niet gevonden word, zijn sulke Teikeningen en Schilderyen redenloos, en meer dan half dood'. Cited in Smith 2004, 213 and Taylor 1992, 210.

184 Taylor 1992, 210 and 213.

185 Hoecker 1916, 184-185: 'Onder al die nachten pleghen te stichten Van verwen op Tafereelen figuerlijck/ Met stralighe wederglansende lichten Con de ouden Bassano de ghesichten Wtnemende wel bedrieghen natuerlijck Want het schijnt datmen siet voor ooghen puerlijc Vlammen/Toortsen/ brandende lampen hangen/ En Potten en Ketels t'weerschijn ontfanghen'.

186 Hoecker 1916, 357.

187 Hoecker 1916, 278-279: 'Om nu wel van t' hoogen den sin bespooren/ sal ick ons verhalen uyt Goltzy spreken/ Hoe Titianus (t'is weerdich om hooren) In eenen Kerstnacht met den 
hoofde vooren Maeckt' eenen Herder/comende ghestreken/ Al waer op 't voorhooft/ om wel doen uytsteken/ Een eenich hoogsel maer en is verschenen/ Daer al de reste vliet bedommelt henen'.

188 Von Sandrart 1675, I, 84, under: http://ta.sandrart. net/edition/text/view/171\#tapagehead [14 Jan. 2014]: 'In grossen Werken/ mus die disminuirung beobachtet werden/ so die Holländer Hauding nennen. Bambots und Rembrand sind hierinn fürtreflich'.

189 Von Sandrart 1675, I, 84. http://ta.sandrart.net/ en/text/172\#tapagehead, 85 [14 Jan. 2014]: 'In einem großen Altar/ oder auf einem andern Blat/ das vielerley Farben bedarf/ ist zu beobachten die disminuirung: daß man nach und nach/ in gerechter Maße/ sich verliere/ und die Colorit ungehintert/ nach der Perspektiv Regeln/ von einem Bild zum andern netto folge und ihr Ort bekomme: welches wir auf Niederländisch Hauding nennen. Diß ist eine sehr nötige Observanz, wird aber wenig erkennet. Und hierinn haben wir zu lernen/von unserm verwunderbaren Bambots, auch von andern/ insonderheit von dem laboriosen und dißfalls hochvernünftigen Rembrand: welche/ wie in deren Leben zu ersehen/gleichsam Wunder gethan/ und die wahre Harmonie, ohn Hinternis einiger besondern Farbe/ nach den Regeln des Liechts/ durchgehends wol beobachtet'.

190 Van Hoogstraten 1678, 305: 'Veel harde schaduwen maeken een schildery een schaekbert gelijk [Book margin, Y.H.]'. Cf. Taylor 1992, 232. Van Hoogstraten 1678, 305-306: 'Daerom beveele $\mathrm{ik} \mathrm{u}$ niet te veel met lichten en schaduwen door een te haspelen, maer de zelve bequamelijk in groepen te vereenigen; laet uwe sterkste lichten met minder lichten minlijk verzelt zijn, ik verzeeker $\mathrm{u}$, datze te heerlijker zullen uitblinken; laet uwe diepste donkerheden met klaere bruintens omringt zijn, op datze met de meerder gewelt de kracht van het licht mogen doen afsteeken. Rembrant heeft deeze deugt hoog in top gevoert, en was volleert in 't wel byeenvoegen van bevriende verwen'. Cf. Bohlmann 2008, 243.

192 Cat. Kassel 2011, 34.

193 Light that is proactive and partakes in the action has, so to speak, an intrinsic quality. Cf. Bohlmann \& Leinkauf 2012, 54.

194 This corresponds with the term 'immanent' light, 'which is emanated by objects that are not

normally sources of light and seem to shine from within'. Bohlmann \& Leinkauf 2012, 55.

Von Sandrart 1675, 327, under: ta.sandrart.net/de/ text/553\#tapagehead [9 Feb. 2014]. 
Stumpfhaus 2007, 62-64: 'Leonardo comments on the actions of people as being endlessly diverse, even in one and the same moment. Therein he identifies the key deficit in capturing figures in motion on a plane surface: the overall image, presented in the right dimensions aided by perspective grids, is a momentary crystallization of the action, meaning that the dynamism of the figures is frozen. (...) [Leonardo] comprehends movement as a continuum that can be divided up into infinitesmal parts. What is represented on a plane surface is just a single moment of continuous successive movement, of an event at a certain point of time in an action. The representation of the action constitutes the event of an instant according to Leonardo'. The event of an instant addressed here corresponds with Van Hoogstraten's 'augenblickliche Bewegung', or 'momentary action'. Leonardo's remarks on this can be found in: Leonardo 1956, 138; see also: Michels 1988, 9-38; Weber 1991, 35; Zöllner 2010. Rembrandt's terminology has preoccupied research since the beginning of the twentieth century. Jan Veth, for example, offered an interpretation based on the more formal aspects of Rembrandt's art, in contrast to H. E. van Gelder, who saw the artist as addressing the emotions or being moved in his notion of 'movement'. Cf. De Pauw-De Veen 1959, 202-211. De Pauw-De Veen illustrated how the concepts of physical movement or being moved emotionally can be viewed as interlinked.

Hoecker 1916, 148-149: 'Maer op den motus des Lichaems van buyten/ T' veranderen en 't roeren der Lidtmaten/ Moeten wy achten/ tot constigher baten/ Dat een yeghelijck mach lichtelijck mercken/ T'geen onse Beelden lijden/ ofte wercken'. sie/ wie die leibliche Zufälle dem Leib/ das
Sandrart 1675,77 , under: http://ta.sandrart. net/edition/text/view/164 [12 Feb. 2014]: 'Die Wirkungen derselben/ werden ingemein die Affecten oder Gemüts-regungen genennet: weil Gemüt afficiren und bewegen'.

Weststeijn 2008, 182.

Weststeijn 2008, 211.

In reference to Van Hoogstraten's Inleyding, Brusati observed that 'this is evidenced in the way the text consistently links knowledge to making and experiment rather than to rhetoric, favouring know-how over knowledge in the abstract'. Brusati 1995, 224.

Roodenburg criticizes Weststeijn in a similar vein: 'He [Weststeijn] rightly related the notion of oogenblikkige beweeging to that of evidentia or energeia (...) but such text oriented explanations (...) may easily neglect aspects of Aristotelian aesthesis, of a period's bodily and sensory engagement with works of art (...)'. Roodenburg 2010, 315-316.

De Lairesse 1740, vol. 1, 135-137.

Kemmer 2004, 103.

Cf. Van Hoogstraten 1678, 292: '(...) 't is niet genoeg, dat een beelt schoon is, maer daer moet een zeekere beweeglijkheid in zijn'.

23 Cf. Von Rosen 2000, 171; Campe 2005, 97-114; Heinen 2010, 159-161.

24 Bredekamp 2010b (237-249) and for the English translation 2018. A definition of Bildakt is: 'images never merely depict, but always also engender what they portray (...)'. Website of the Kolleg-Forschergruppe Bildakt und Verkörperung http://bildakt-verkoerperung.de/en/zielsetzungen/ [16 Jan. 2018].

Bredekamp 2018, 200.

Bredekamp 2010a, 459: '(...) die Möglichkeit, im Blick komplexe Zusammenhänge in der extrem kurzen Zeit des subito erfassen zu konnen, begründete für ihn [Roger de Piles] die Höherrangigkeit der Kunst über die Dichtung'. Leonardo 1995, 17: 'La pittura ti rappresenta in un subito la sua essenza nella virtú visiva, e per il proprio mezzo d'onde la impressiva ricevi gli obbietti naturali, ed ancora nel medesimo tempo, nel quale si compone l'armonica proporzionalità delle parti che compongono il tutto, che contenta il senso'. Cf. Bredekamp 2010a, 459 .

28 Vos 1726, vol. 1, 361: 'The unexpected has incredible power' ('Een onverwachte zaak heeft overgroote kracht'). Quoted after Weber 1991, 199. Van Hoogstraten 1678, 116.

30 For the term 'unclassical', see the classic book by Werner Busch (2009). Concerning the Carracci and Laurence Sterne, see: Busch 2011a, 122-124.

31 Jennifer Montagu established that for Lessing, too, albeit based on other premises, it was important to capture a single moment 'in a continuing process of movement'. Montagu 1994, 3. Roodenburg sees the difference between Van Hoogstraten and Lessing in the latter calling 
the fertile moment 'pre-climactic' as opposed to Van Hoogstraten's oogenblikkige beweeging. Roodenburg 2010, 315 .

Weber 1991, 197: 'Um aber im Bilde auch den Ablauf der Handlung selbst - und nicht ihren einen beschließenden Moment - suggerieren zu können und ohne zugleich die Wahrscheinlichkeit der zeitlich eingeschränkten Darstellung zu verletzen, kann der Maler einen Augenblick wählen, in dem der Lauf des Geschehens entscheidend umschlägt'. See Chapter I, 19-20.

34 Busch 2011a, 123.

35 For instance, see: De Lairesse 1740, vol. 1, 28-35 and 65-106. Weber 1991, 197: 'But in order to render the suggestion of an action sequence in the plot and not the conclusive moment, without offending the laws of probability in regard to time, the painter may select the moment in which there is a sudden reversal of fortune in the action. The extent to which this change of mood can be at all depicted is only possible if the artist can combine the different moods in the one figure'. Roodenburg came to a similar conclusion: 'Accordingly, Jelgerhuis described the actor's movements on stage as, a quickened sequence of attitudes, of, so to speak, a succession of permanent picturesque movements of arms and hands, legs and feet, and turning of the head'. Roodenburg 2004, 158.

This aspect of faith as a physical ritual recalls Althusser's interpretation of a dictum of Pascal: 'The outer must unite with the inner to unite with God, that is, one must kneel down and pray with the lips (...)'. Althusser 2000, 124.

After an acid attack in 1971, the lower part of the face was severely damaged. The painting was then restored.

38 In a 166o poem Jeremias de Decker praised the painting of his friend: '(...) Where (I think to myself) did the brush ever come so close to the pen, in bringing lifeless paint so close to life? (...) It seems that Christ is saying: Mary, tremble not. (...) The grave-rock rising high in the air, as art requires, And richly shadowed, dominates the painting and gives majesty to the whole work. (...) Your masterful strokes, friend Rembrandt, I first saw move on this painting. Thus, my pen was able to speak on your talented brush and my ink to praise your paints'. The poem was published in De Groot 1906, 268. For the
English translation, see: Van de Wetering 2010, 234. Cf. Konst 1990, 298-312. For Rembrandt's Portrait of Jeremias de Decker, see: De Raaf 1912, 1-5.

39 Cf. Bikker 2005, 63-65.

40 Van Hoogstraten 1678, 120.

41 Cat. Hamburg 2006, 88-90. For the comparison between Lastman's and Rembrandt's Dismissal of Hagar, see: Sitt 2004, 292-294.

42 Cat. Amsterdam etc. 2004, 30.

43 Cf. Cat. Munich 2004.

44 Cf. Schneider 2012, $5^{6-58 .}$

45 The use of colour cannot be discussed in greater detail because the painting, now lost, is known only in black-and-white reproductions.

46 Cf. Chapter I, $55^{-58 .}$

47 Van Hoogstraten refers to these terms, as discussed above, in the section 'Van de doening, in de daed der Historie'. Van Hoogstraten 1678, $115^{-116 .}$

48 Van Hoogstraten 1678, 116.

49 Van Hoogstraten 1678, 109: 'de eygentlyke bewegingen den lichaemen nae haere doeningen toe te passen'.

50 Van Hoogstraten 1678, 116.

$51 \quad$ Pächt 1991, 161.

$5^{2} \quad$ Schwartz 2006, 310: 'Eher als für die spezifischen menschlichen Verhaltensformen schien Rembrandt sich für den mentalen Zustand hinter einer Handlung zu interessieren. Dabei brauchte es gar keine Aktion zu geben'.

53 Van Hoogstraten 1678, 117: 'Wat de handen belangt, door dezelve worden voornamentlijk alle daden ofte doeningen uitgewerkt, ja der zelver beweegingen zijn byna by een algemeene spraeke te vergelijken'.

54 Quintilian: Institutio Oratoria, 11.3.85, 4:289, quoted after Lichtenstein 1993, 102.

55 See Houbraken 1753, vol. 1, 270 and 264: '(...) honderden (...) van schetsen (...) waar in de driften van 't gemoed ontrent allerhanden voorvallen zoo konstig en duidelyk zig in de wezenstrekken vertoonen dat het te verwonderen is. (...) Stel eens, men moet vreugt, blydschap, droefheid, schrik, toorn, verwondering, veragting enz. dat is, de menigerhande leidingen van de ziel, door vaste en kennelyke wezenstrekken vertoonen'. Cf. Rosand 2002, 226. For the relation between Arnold Houbraken and Samuel van Hoogstraten, see: Horn 2013a, 208-239. 
Dethlefs 2009, 221-222: 'Der Bilder Natur-artige und wohl-sittliche action'. Cf. Chapter II, 100-102. Weber 1991, 206. Cf. De Lairesse 1740, vol. 1, 135-137. De Vries 1998, 192. Cf. Montagu 1994, 126. Le Brun 1698 (Montagu 1994, 112-113): 'Comme il est donc vrai que la plus grande partie des passions de l'Ame produit des actions corporelles, il est necessaire que nous sçachions quelles sont les actions du corps qui expriment les passions, \& ce que c'est qu'action. Laction n'est autre chose que le mouvement de quelque partie, \& le mouvement ne se fait que par le changement des muscles, les muscles n'ont de mouvement que par l'entremise des nerfs qui les lient \& qui passent au travers, les nerfs n'agissent que par les esprits qui sont contenus dans les cavités du cerveau, \& le cerveau ne reçoit les esprits que du sang, qui passe continuellement par le coeur, qui l'échaufe \& le rarifie de telle sorte qu'il produit un certain air subtil qui se porte au cerveau, \& qui le remplit. Le cerveau ainsi rempli renvoie de ces esprits aux autres parties par les nerfs qui sont comme autant des petits filets ou tuiaux qui portent ces esprits dans les muscles, plus ou moins, selon qu'ils en ont besoin pour faire l'action à laquelle ils sont appellés'. Cf. Held 2001.

Cf. Fischer-Lichte 2004.

The term 'iconicity' brings Max Imdahl and the studies by Gottfried Boehm or John Michael Krois to mind. For Imdahl and Boehm, the body is not as strongly linked to iconicity and to the perception of pictures as it is for Krois. Cf. Imdahl 1979, 424-463; Krois 2011b, 211-231; Boehm 2012, 28-92.

Cf. Trabant 2012, 77-92.

Current research on mirror neurons testify this, although it ignores the historical dimensions of perception: Freedberg/Gallese 2007. For some historical examples, see: Chapter VI, 246-250.

See the classic study by Baxandall 1972 and his notion of 'period eye', which in this context could be expanded into a period body.

Noë 2004, 25 .

Weststeijn 2009, 427.

Von Rosen 2000, 184.

Van Hoogstraten 1678, 293: 'Zoo is 't ook met de Schilders, zy beroeren 't gemoed niet, zooze deeze beweeglijkheyt overslaen (...)'. Weststeijn 2005,117 .

69 Junius speaks of beweghens kracht. Junius 1641, 274, quoted after Weststeijn 2010a, 279. The power of paint is a product of the handeling and can move the beholder of its own accord. Cf. also Roger de Piles' statements, in: Kirchner 1991, 61.

71 The degree in which handeling is to be viewed as the visual action representing a mood is evidenced in Bellori's biography of Domenichino (1672): 'And he [Domenichino] would add that in dealing with actions in painting, it is necessary not only to contemplate and come to know the emotions to be depicted but also to feel them in oneself, to do and suffer the very things that are being represented; hence at times he could be heard talking to himself and uttering cries of sorrow and joy according to the passions expressed'. Bellori 2005, 266. Here certain topoi north of the Alps conflate with those of the south. They demonstrate how a number of painting principles from idealized art theory were perceived and described in a similar way. Therefore, a geographic differentiation makes little sense after all, it is a genuinely European phenomenon. Though Domenichino adhered to the fine manner, he gave his depiction of the emotions a performative dimension. In this he was similar to the Rembrandtists, though they even enhanced the specific relation of form and context through their painting approach's additional discrepancy between an object and its depiction.

Houbraken 1753, vol. 3, 208. 'Het laatste van zyne werken is de Passie, anders de Historie van den lydenden Christus, in 22 stukken, war van' er reets voltooit zyn, waar in konstig de menigerhande hartstogten, of gemoedsdriften uit kennelyke wezenstrekken te zien zyn'. See Hadjinicolaou 2014b. Translation Herman Roodenburg. Cf. Chapter II, 84. In this context Junius believed that 'an Artificer therfore who desireth to moove the spectator with his worke (...) had need to be mooved himself'. Junius 1991, vol. 1, 264.

74 Constantijn Huygens, as well as Houbraken, praised the then-young painter for his affectuum vivacitas. Houbraken probably learned this from his teacher, Samuel van Hoogstraten. 
Roodenburg speaks in this context of 'kinesthetic empathy' and 'corporeal and sensory dimension'. Roodenburg 2010, 311 and 316.

Cf. Alpers 1988. Alpers is among the few to focus on the corporeal aspect of Rembrandt's work, at least rudimentarily, in her research and writings. Houbraken 1753, 163: 'zyne Discipelen by wylen tot verversinge hunner opgespannen gedagten, een schaduwdans vertoonen, of spelen: dienstig niet alleen tot vermaak, maar in zonderheid om hen door zulk een voorwerp, de menigvuldige veranderingen en verlengingen of verkortingen der licht verwisselende gedaanten der schaduwen, (spruitende uit de nabyheid of afstand van 't licht) te doen kennen en begrypen'. Translation Herman Roodenburg.

78 Roodenburg 2010, 312.

79 Van Hoogstraten 1678, 109. 'Van de dristen des gemoeds, lijdingen der ziele, ofte Hartstochten staet ons dan eerst te spreeken. Leer nu, ô Schilderjeugt, deze allerkonstichste rol speelen (...) Wilmen nu eer inleggen in dit alleredelste deel der konst, zoo moetmen zich zelven geheel in een toneelspeeler hervormen. Ten is niet genoeg, datmen flaeuwelijk een Historye kenbaer make (...)'. Van de Wetering 2010, 68-69.

8o Van de Wetering 2010, 259-261.

81 Stoichita 2000, 137-138; Bredekamp 2004, 71-73.

82 Van Hoogstraten 1678, 110. 'Dezelve baet zalmen ook in 't uitbeelden van diens hartstochten, die gy voorhebt, bevinden, voornaemlijk voor een spiegel, om te gelijk vertooner en aenschouwer te zijn'. Translation in Weststeijn 2008, 183. De Piles is close to Van Hoogstraten both regarding empathy (in the use of the mirror) and in his observations of the dumb on account of their gesticulation. Cf. Kirchner 1991, 57 and 116. Franciscus Junius and Gerard de Lairesse recommend much the same.

83 '[S]peel de historyen, en yder personaedie eerst in uw gedachten'. Quoted after Weststeijn 2008, 163 .

84 Van Hoogstraten 1678, 117. Cf. Weststeijn $2008,182$.

85 Van Hoogstraten distinguished between the work of the artist and that of the actor. He recommended that artists do not render their figures as if they were dumb actors. In this he is diametrically opposed to De Lairesse, who recommended that artists visit the theatre and find inspiration there. Van Hoogstraten 1678, 190:
'Laet uwe figuuren met malkanderen een welstandige beweging hebben: niet als de domme toneelspeelers, die de reedenen, dieze elkander behoorden toe te duwen, voor op 't toneel aen de toehoorders komen uitbraken'.

86 Houbraken 1753, vol. 2, 162-163: 'T is gebeurt dat een van zyn Discipelen de schets van zyn ordonantie (gelyk ieder alle week doen moest) aan hem vertoonde, maar weinig agt gegeven had op de regte werkinge der beelden, die hy zoo maar had neergestelt. Straks was het zeggen, Lees den Text; en gevraagt, Wil dat nu het Beeld wezen dat zulks zeit? antwoorde zy dan Ja, zoo was gemeenlyk zyn zegge: Verbeeld u eens dat ik die andere Persoon ben, daar gy zulks tegen moet zeggen; zeg het tegens my. Als zy dan de reden volgens de letter van de Text, zonder aandoeninge, met de handen in de zak, of als stokbeelden uitspraken, was zyn zeggen: de zakken zyn gemaakt om dat het geld in 't dragen niet door de vingeren zoude druipen; en stond met een van zyn plaats op en liet den Discipel daar zitten, zeggende: Nu zal ik het u voordoen, let op de Gebaarden, wyze van staan, of buiging des lichaams, als ik spreek, en beduide het (als het spreekwoord zeit) met vinger en duim. (...) Om van deze gebaarden, en roeringen die een Konstige Redevoeringe behoorden te verzellen, zyne Leerlingen een vaster indruk te geven, en zig daar aan meerder te doen gewennen; koos hy de bekwaamste van zyne Discipelen uit (...) en gaf hun yder een Rol van zyne, of een's anders Toneelstuk te spelen: tot het welke zyden vermogten hunne Ouders en goede Bekenden te noodigen, tot aenschouwers, van het Spel [...]'. Translation from Brusati 1995, 87.

87 For the notion of the artist as Pathopoios, see: Weststeijn 2008, 171. It is revealing that in Greek an actor is called ethopoios, that is, one that engenders ethos and not pathos. See Roodenburg 2015 .

88 Brusati 1995, 89-90.

89 Fischer-Lichte 2001, 12.

90 Diderot 1883.

$91 \quad$ Smith 2004, 238.

92 Smith 2004, 239.

93 Houbraken 1753, vol. 3, 207: ‘(...) gelyk hy dan ook voor gebruik houd, zynen Leeman van hoofd tot teen te bekleeden, en in zulk een gedaante te zetten, als hy noodig heeft, 't geen hy dan met het penceel, of met duim en vinger 
nabootst'. On how jointed dolls were used and their import, see: Kleinert 2006, 77-81; Chapman 2008, 188-215; Rath 2016. Joachim von Sandrart mentions - in the chapter on 'Painting Garments and Fabrics' in his Teutsche Akademie - that the role of the jointed doll as a model can be beguiling at times: 'Above all, it is in the garments and their colours and folds that the difference of age, social standing and position of the figures can be observed, or their gender, or whether they practice traditional national customs or modern and are very different in their mores. To understand their various ways, it is wise to diligently observe how all of this operates in life and to make so-called wax models or use jointed dolls clothed in dresses and coats of rough linen or drape them with wet paper: which then produces pleasant folds and is very useful, if applied with measure, before beginning on a large composition. However, care must be taken, as motion is missing'. See Sandrart: 1675 , 82, under: http://ta.sandrart.net/edition/text/ view/169\#tapagehead [12 Feb. 2014]. Weststeijn 2008, 163-164.

For this practice, see: Perrig 1976. Cf. Scholten 2017.

Houbraken 1753, vol. 1, 261: 'Hier in word ik te meer verzekert, om dat verscheiden van zyne Leerlingen my hebben verklaard, dat hy somtyds een wezen wel op tienderhande wyzen afschetste eer ha 't zelve op paneel bragt (...)'.

Konstam 1977, 97.

For instance, see the drawing attributed to Constantijn van Renesse, Rembrandt and his Pupils Drawing from a Nude Model, in: Cat. Amsterdam 2014, 120.

Konstam 1977, 97. In his Inleyding, Van Hoogstraten underscored that Giorgione used mirrors to make things visible from different angles simultaneously. Cf. Van Hoogstraten 1678, 275: 'Het verstant van deeze konst gaf aen Giorgione de stourigheyd van staende te houden (...) en van vooren in een glad afstraelende waeterqueel te zien was'. Simmel's description at the beginning of his seminal book on Rembrandt sums up the phenomen in a nutshell: 'expressive meaning of the movement in its entirety is incorporated in the very first brushstroke; and therefore, this brushstroke is pregnant with the view and sense

of emotional and physical movement fusing into one'. Expression, movement, and meaning converge in the first brushstroke and constitute an indivisible whole. Simmel 1916, 4 .

101

102

103

104

105

106

107

See for example Chapter 4, 182.

Roger de Piles 1706, 32.

Van Hoogstraten 1678, 292-293.

Van Hoogstraten 1678, 116.

Weber 1991, 206.

Bredekamp 2010b, 239-241.

De Lairesse 1712, vol. 1, 136: 'De reden daar van is, dat deze [...] Beeltenissen zodanig doorwrocht en gelykvormig met de menschelyke gedaantens over een kwamen, dat zy niet als geschildert, maar vleesch en bloed, ja als beweegende beelden, vertoonden'. Cited in Weststeijn 2008, 145 .

108 For similar ideas, see: Walton 1990.

109 Goeree 1682, 337-338: 'Nadien de Konst-Beelden uyt haar eygen Natuur het Leven en de beweging derven; dat sulx ons te meer vermaand na Middelen om te sein, waar door de Beelden in de Tafereelen soodanig konnen voortgebracht werden, datse den Beschouwer alle gedagten van doek en panneel, verf en olye, ofte van hout en steen en koper, soose mogten gegoten of Geboedseerd zijn, konden doen afleggen, en een Denk-Beeld geven dat hy niet geschilderte noch Gegotene, maar Natuurlijk Levende Menschbeelden voor zijn Oogen meend te sien. Invoegen dat hem dunkt datse Loopen, datse gaan, spreken, roepen, vegten, hooren, zien, denken en alle andere Levende Actien van bezielde Menschen doen'. Translation by Herman Roodenburg. Cf. Roodenburg 2010, 314.
Sluiter 1998b, 71-85 and 240 .

Lilienfeld discerned a strong tie to Giovanni Domenico Tiepolo. Lilienfeld 1914, 116. The perspective and the plastic quality of the figures in this painting are even more radical than in corresponding pictures by Rembrandt, that is, his paintings, prints, and drawings, with which De Gelder was familiar. Joshua Bruyn compares the Passion cycle to the work of Gustave Doré and Goya. Cf. Sluiter 1998b, 83 .

This is in the tradition of Timanthes' attempt to paint Agamemnon, mentioned by Van Hoogstraten (Van Hoogstraten 1678, 111). Sluiter 1998b. Sluiter surprisingly does not attempt to see a connection between 
Houbraken's description of the Passion cycle and the paintings. His assertion that De Gelder does not depict emotions is problematic. It might be true in a straightforward way regarding the facial expressions of the figures; however, in exciting the emotions, this painting does not rely solely on their physical manifestations in the figures, but also in the handeling. The pending storm underscores this, as, by all appearances, it comprises a storm of paint.

115 The paintings were listed in the artist's inventory together with many other works by his own hand. Cf. Lilienfeld 1914, 272-286. Jeremias de Decker's Goede Vrijdag ofte Het Lijden onses Heeren Jesu Christi (1651) may have played a role in this, as Sluiter also mentioned (Sluiter 1998, 84-85). De Decker and De Gelder both lived in Dordrecht and the author was also a friend of Rembrandt. The language De Decker used is packed with emotive and intersensory analogies and might have inspired De Gelder for the imagery for his Passion series. See De Decker 1958. Van de Wetering (Corpus v) considers Rembrandt's small-format history paintings as well as his Passion cycle as having served as the artist's fields of experimentation. The following quote from the beginning of the twentieth century proves to be also relevant for De Gelder's painting, where the beholder comprehends the dynamism as the intrinsic plot: 'One penetrates things, both animate and inanimate, with one's feeling for movement and plasticity. (...) One perceives even in the inanimate the impression of a process'. Volkmann 1908, 15. This idea is linked to the notion of intuition, which had a stellar career with Friedrich Theodor and Robert Vischer as well as with Theodor Lipps or Hermann Lotze through to Wölfflin, Schmarsow, or even Berenson in art history. Cf. DidiHuberman 2010b, 446. Wölfflin 1886. See Dickey/ Roodenburg 2010, 9-10. Empathy plays a decisive role today in embodiment theory (enactivism), or the mirror neuron debate. Freedberg/Gallese 2007, 197-203; Fingerhut 2012, 177-198.

116

117
Van Hoogstraten 1678, 167 .

Van Hoogstraten 1678, 121: 'Pithagoras Leontinus maekte zynen Hinckepoot zoodanig, dat d' aenschouwers de smerte zijns verzwooren beens meenden te gevoelen'.

Weststeijn 2008, 203.
119 Weststeijn 2008, 290: 'Het beelt van Hector in de stad trojen opgerecht (...) dat den aenschouwer lust krigt om het aen te roeren'.

120 Cf. Chapter vi.

121 De Brune de Jonge 1994, 169: 'Ik durfze raken naauw/ Op daat haar poesle vleesch, geen kneep en krijg', of kraauw:/ Want zy is gemaalt, z' is levend' en waarachtigh/Zy weet geluit te slaan dat yeders ziel bemachtigh'. Quoted after Weststeijn 2008, 151 and 393. Van Hoogstraten relates the story of Samuel Pepys' impelling desire to touch the drop of water in a fruit still life.

Weber 1991, 204.

In his book Pictures and Tears, James Elkins lets Jane Dillenberger have her say about what she experienced beholding a painting by Rothko. This is a case of describing a viewing experience for a twentieth-century work that is potentially valid for how the works of the Rembrandtists were meant to be viewed: 'I felt as if my eyes had fingertips (...) moving across the brushed textures of the canvases.' Elkins 2004, 2-3. Rothko is an artist for whom paint was a highly emotive medium - one that plays a special role, similar to the Rembrandtists.

124 Gell 1998, 29. Gell, however, focused too strongly on a schematic separation of the interaction between passive and active poles, as for example the active beholder in viewing a passive work of art and vice versa. See the criticism of Frank Fehrenbach (2010, 130-131).

125 Busch 1993, 324-326; Kirchner 1991, 369; for Chodowiecki, see: Kirves 2012.

126 For the difference between body schema (unconsious) and body image (consious): Gallagher 2006; Krois 2011c, 253-271.

Mauss 1975, vol. 2, 199-220. Cf. Fischer-Lichte 2001, 18.

\section{Proximity and Distance}

Sedlmayr 1934, 137-160; Sedlmayr 1959, 282. 'Die Menge der Farbflecken ist ungeordnet, bunt durcheinandergewürfelt; außerdem führen die Farbflecken ungeordnete Scheinbewegungen aus, sie scheinen nach allen Richtungen durcheinanderzuschwimmen. Dem entspricht in der gegenständlichen Sphäre die Unordnung der Dinge und Körper mit ihren Steigerungsformen 
des "Wirrwarrs" und “Trubels" und des völlig sinnlosen Chaos, wie die ungeordneten und chaotischen Formen der Bewegung. Beides hängt eng zusammen mit dem Phänomen der Masse'. Cited in Sedlmayr 2000. Quoted after Imdahl 2003, 173: 'A plain macchia, without being determined objectively in any way, is certainly capable of moving [beholders] emotionally and creating some sort of sensation in them'. Rosenberg 2004, 42. De Piles substituted the word composition for macchia. See Chapter IV (second part).

$5 \quad$ See Chapter IV, 184.

6 Boschini 1966, 327: 'Vedo un impasto, un sprezzo de penelo/ Un certo che inefabile e amirando/ Che soto l'ochio ne va a bulegando (...)'. Cited in Sohm 1991, 150. Cf. Chapter IV (third part). Chapter IV (second part). Cf. Chapter IV (first part). See Chapter III (third part). Cf. Von Sandrart 1675, I, Book 3 (Painting), 86, under: http://ta.sandrart.net/edition/text/ view/173\#tapagehead [22 Jan. 2014]: 'At the beginning, as our wise Creator, who made all things that are visible, by creating light discovered the chaos or inchoate clumps out of which all was made. All colours were mixed together into this chaos until they were separated into individual colours. After all things were given their shape they were again hidden from view in the dark of night and became visible by daylight'. Sandrart borrowed this passage from Mander's Grondt. Cf. Hoecker 1916, 285: 'As the dark void reigned, or as the poets say, chaos pervaded, before order was brought into things and the air was without light, drowned in darkness, colours and their various names did not yet exist and were concealed, to be revealed only later'. Cf. Chapter III, 176. For the role of creation out of chaos, see: Fricke 2010, $33-58$.

Cf. Boehm 2003, 48-59. See this epilogue, 274-276.
Vasari 1998, 503-504; Vasari 2005, 45. Cf. Vasari 1965,332 : 'Ma è ben vero che il modo di fare che tenne in queste ultime è assai diferente dal fare suo da giovane. Con ciò sia che le prime son condotte con una certa finezza e diligenza incredibile e da essere vedute da presso e da lontano, e queste ultime, condotte di colpi, tirate via di grosso e con macchie di maniera, che da presso non si possono vedere e di lontano appariscono perfette'. See Cranston 2010, 2. Lomazzo similarly described how Aurelio visited Titian's workshop, where essentially the same description given by Vasari was adapted to a landscape painting. Cf. Busch: 1997, 97: 'At first glance Aurelio thought it was just a lot of smears, but when he took a few steps back and viewed it from a distance, it seemed to him as if the sun was shining within the picture and the paths here and there dissolved in air'. In the biography of Luca della Robbia, Vasari also gives a favourable account of the rough sketch in Donatello's design for his Cantoria, owing to both the pragmatic function of where it was hung as well as the artistic ingenuity displayed in only a few brushstrokes: 'Above the framework of this decoration Luca made two figures of gilt metal representing two nude angels, beautifully finished, as indeed was the whole work, which was considered most rare. It is true that Donatello, who afterwards did the ornamentation of the other organ opposite this one, displayed much more judgement and skill than Luca, as will be said in the proper place, because he did almost the whole of the work in the rough as it were, not delicately finishing it, so that it should appear much better at a distance than Luca's; as it does, for with all his care and skill the eye cannot appreciate it well because of the very polish and finish, which are lost at a distance, as it can the almost purely rough hewn work of Donato. To this matter artists should devote much attention, because experience shows that all things seen at a distance, whether they be paintings or sculptures or any other like thing, are bolder and more vigorous in appearance if skilfully hewn in the rough than if they are carefully finished. Besides the effect obtained by distance, it often happens that these rough sketches, which are born in an instant in the heat of inspiration, express the idea of their author in a few strokes, while on the other hand too much effort and diligence sometimes sap the vitality and powers of those who never know when to leave off'. Vasari 1963, 225. 182. 
Houbraken 1753, vol. 1, 269: '(...) door welke wyze van behandelen zyne stukken, zelf in wyden afstand, kragtig uitkomen'.

Cf. Rembrandt's letter of 12 January 1639 to Constantijn Huygens (Chapter v, 196). Roger de Piles held similar views about the power of paint in Rembrandt's art when viewed from a distance. See De Piles 1706, 320.

Houbraken 1753, vol. 1, 269.

Wurzbach 1970, 369 .

Slive 1988, 119. Cf. Félibien 1685, vol. 4, 150-151.

Slive 1988, 119 .

Slive 1988, 119. Reynolds, an opponent and critic of Gainsborough, nevertheless understood the importance of proximity and distance with respect to the latter in painting. Cf. Busch 1993, 171-178.

Burín 196o, vol. 2, 87 and 92. Cf. Warnke 1997a, 13. Cf. McKim-Smith et al. 1988.

Beritens 1914. Cf. Hadjinicolaou 2019.

Reynolds 1997, 258.

It is not a coincidence that in keeping with Vasari, Francesco Bocchi wrote in 1591 that: '(...) these sketches (bozze) are without any beauty from nearby, but appear fierce, marvelous, yet graceful from much further away'. See Sohm 1991, 50 .

25 Boschini 1966, 74-76. Cited in Sohm 1991, 141. There is the hint of a similar affirmative attitude toward viewing from close-up in Balzac's Le Chefd'œuvre inconnu (The Unknown Masterpiece) when Frenhofer encourages Poussin and Porbus to move closer to the painting so that they 'see the manner of working better; at a distance, it cannot be seen'. Balzac 2007. Cf. Didi-Huberman 2002, 169-170.

Van Hoogstraten 1678, 27: 'En even gelijk men zijn vriend van verre bespeurende, of by schemerlicht ontmoetende, strax als met het verstant zijn gedaente ziet, en bevat, zoo geeft een ruwe schets dikwils aen den kenders zoo grooten indruk, dat zy 'er meer, dan dieze gemaekt heeft, in zien kunnen'. The connoisseurs can see more in the few amorphous stains because they stimulate their imaginations. In another passage (340) Van Hoogstraten (in the tradition of Horace) favours both options of viewing: 'De Schilderkonst, dewijlze alleenlijk verbonden is, ' $t$ zy van naby of van verre (...)' [authors' italics]. Cited in Lichtenstein 1993, 162.

8 Scaramuccia 1674, 106. Cf. Von Rosen 2001, 342.
Hagedorn 1997, vol. 2, 756. Quoted after Wagner 2013, 259: 'mehr mit den Händen als mit den Augen'.

Cited in Slive 1988, 121.

Zanotti 1703, 102. cf. Suthor 2010, 93.

Suthor 2010, 75-77.

Sohm 1991, 141; Cranston 2010, 4.

Sohm 1991, 50 and 147.

Boehm 2012, 28-92. See the remarks on proximity and distance in Hogrebe 2014, 16-26.

Boschini 1966, 166, cited in Sohm 1991, 242.

The role of Houding was thematized in Chapter IV (187-189).

38 Van Hoogstraten 1678, 307: 'Ik zeg dan, dat alleen de kenlykheyt de dingen naby doet schijnen te zijn, en daer en tegen de egaelheyt de dingen doet wechwijken: daerom will ik, datmen 't geen voorkomt, rul en wakker aensmeere, en 't geen weg zal wijken, hoe verder en verder, netter en zuiverder handele'. Cf. Berghof, 2010, 196. Cited in Van de Wetering 2004, 183-184.

39 Van Hoogstraten 1678, 307: 'Noch deeze nog geene verwe zal uw werk doen voorkomen of wechwijken maar alleen de kenlykheyt of onkenlykheyt der deelen'. Cited in Van de Wetering 2010, 12. Berghof 2010 (197-198) criticized Van de Wetering and turns Van Hoogstraten's statement upside down (202): '(...) what is close will appear brighter or more vibrant due to the strength of the beams of light, but what is in the distance may revert to the aggregate representational brightness of what may have been a series of bright as well as muted shades of colour'. The question is for which kind of painting is this supposed to be relevant: a Rembrandt or a Vermeer? In this context Diderot's later thoughts on the paintings of Chardin are important. Both Chardin and the Rembrandtists are concerned about disrupting any illusion that is not confined to a logical, optical understanding. Cf. Gockel 2011, 74-76.

This issue has been discussed at length in art historical literature. See Warnke 1970, 88-106. Cf. the seminal book by Arasse 1992.

41 Van Hoogstraten 1678, 307.

42 See Chapter I, 32.

43 Sandrart 1675,72 , under http://ta.sandrart.net/ en/text/159\#tapagehead [21 May 2014]: 'Aber in seinen letzten Zeiten und Jahren/ mahlte er sehr rauh/ mit vielen Farben beschwert: welches in der Nähe nicht/ aber nur von weitem/ sehr 
wol gestanden'. At the same time, Joachim von Sandrart discusses the function of painting in this way in a certain context: 'Others, who are to be part of the background, are to be hastily rendered using dark hues that gradually wane in the distance'. Sandrart 1675, 62, under http://ta.sandrart.net/en/text/149\#tapagehead [21 May 2014].

Sandrart 1675, 62, under http://ta.sandrart.net/ en/text/149\#tapagehead [21 May 2014].

Van Hoogstraten 1678, 235: 'Nu zoo moetmen ook zijn handeling voornamentlijk veranderen na de plaets (...) die by zich zelven steekende zijn'. Cf. Van de Wetering 2010, 117: 'One should also adapt his brushwork [Handeling] according to the place where the work has to stand: for you will assuredly regret it if, in painting a piece that has to hang high up, and has to be seen from a distance, you have wasted much time on small things. (...) for the height and the thickness of the air will show many things merged together which should [seen closer] stand out separately' See Chapter I, 31. Proximity during the painting process evokes precision, whereas distance and painting with a longer brush creates fuzziness. De Lairesse 1740, vol. 1, 315-319. Cf. De Vries 2011, 67. On page 131 De Vries observed: 'De Lairesse points out that one should never forget that colours loose much of their intensity when seen from a great distance'.

Alva Noë made a similar observation in another context: 'To see one must have visual impressions that one understands'. Noë 2004, 6 .

Noë 2004, 7 .

'In der Nähe betrachtet, scheint aber das wüsteste Farbenchaos die wildesten Orgien zu feiern. Wohl sollte dieses furiose Umspringen mit den Farben und deren Wirkung in die Ferne eher als der wundervollste Kunstausdruck angestaunt werden; aber die Menge ist nun einmal so: Was sie nicht versteht, wird von ihr verdammt'. Cf. Stückelberger 1996, 189-190. Schröder 1992, 8-35. Justi 1902, 5. 'Undeutlichkeit der Gegenstände' 'Wildheit des Pinselstrichs'.

Justi 1902, 6: '[D] as Unklare und Zerflossene, das Sinnlose und Unzulängliche wird als höchstbewertete Stilqualität angestaunt'.

Following Georges Bataille, Georges DidiHuberman asserted that in regard to the role of the inchoate we can only conceive form as perpetual chance or accidental form. Didi-
Huberman 2010a, 200. This appears to refer directly, as a kind of unconscious forerunner, to a statement by Marco Boschini in which he asserts regarding the rivalry between sculptor and painter that 'the painter uses form without form, or rather with form deformed, and finds the true formation in fluid form'. Boschini 1966, 750; Cited in Sohm 1991, 155 . Koos 2008, 133-16o.

Sohm addressed the subject of feeling a painting in writing how 'Boschini loved to rub his fingers over the sharp edges of Bassano's work as if his touch could help him to understand the densely jagged surfaces'. Cf. Sohm 1991, 6 .

For the question of scale and the effect of detail on small format, see: Scholten 2016, 171-211. Cf. Cat. Kassel 2001, 32.

Fehrenbach 2005, 20. Cf. Von Rosen 2000, 190: 'The disappointment after touching a painting, as Zuccaro relates, is only anecdotal'. Referring to the art theory of the Netherlands, Weststeijn, in contrast, argues that ' [...] the two-way movement of ocular exchange means that while the beholder's senses are taken over by the painter's illusionistic skills, the art object itself changes too, from a lifeless material object into an animated reality'. Weststeijn 2010b, 160 . Weststeijn's significant observation reveals a problem that is based on his interpretation of what virtual reality is. Presumably, it is rather relevant to the fine manner of painting.

Krois 2011a, 149.

9 Krois 2011b, 214-215: 'Der Begriff des “Tastens", verstanden als das Tasten mit den Fingern [ist] zu eng, um die Dimension der haptischen Wahrnehmung zu erklären. Räumliche Wahrnehmung ist unabhängig vom Sehen und auch vom Tasten mit den Fingern - sie stützt sich auf die ambulante Körperlichkeit des Menschen: auf Propriozeption und Kinästhesie'.

Kennedy 1993; Kennedy/Hammad 2012, 72-73. See also Arnheim 1992, 133-143.

$61 \quad$ Krois 2011c, 265: '[Der Mensch] muss sich bewegen können und daher im Besitz eines Körperschemas sein. Dieses bildet unbewusst ein Modell der Körperhaltung heraus, das kein Sehbild ist, sondern eine Art Tastbild'. Riegl 1973, 27-35. Didi-Huberman 2002, 89; cf. Krois 2011b, 213; Rath et al. 2013, X-XI. See Schwarte 2011, 211-213. 
63 Riegl 2004, 396; Riegl 1966, 287: 'Aber gerade der Gesichtssinn als solcher ist ungenügend, um uns die Empfindung der Form zu verschaffen. (...) Es bedarf eines anderen Sinnes, um uns vom Vorhandensein der Tiefe zu überzeugen, und daß ist der Tastsinn. Der Gesichtssinn verrät nur das Vorhandensein eines Dinges; die Form des Dinges erkundet erst der Tastsinn. (...) So hätten wir ein Wesentliches: die Form, die uns der Tastsinn lehrt, und ein Trügerisches, Scheinbares: die Fläche, die uns der Gesichtssinn vorspiegelt. Diese Fläche nennen wir die optische oder subjektive Fläche'.

64 Riegl 2004, 400; Riegl 1966, 291. 'Daher ist plastisch und malerisch mit nahsichtig und fernsichtig zu übersetzen'.

65 Wölfflin 1886.

66 Wölfflin 1915. Cf. Krois 2011b, 212.

$67 \quad$ Körner emphasizes the fact that Herder's understanding of sculpture was more visual than haptic: Cf. Körner 200o, 182. Cf. Wagner 2008, 44.

68 Wölfflin 1950, 21. Wölfflin 1915, 23-24: ‘die Operation, die das Auge ausführt, der Operation der Hand gleicht, die tastend am Körper entlanggeht, und die Modellierung, die in der Lichtabstufung das Wirkliche wiederholt, sich ebenso an den Tastsinn wendet. Eine malerische Darstellung dagegen in bloßen Flecken schließt diese Analogie aus. Sie wurzelt nur im Auge und wendet sich nur an das Auge, und wie das Kind sich abgewöhnt, alle Dinge auch anzufassen, um sie zu begreifen, so hat die Menschheit sich abgewöhnt, das Bildwerk auf das Tastbare zu prüfen'. Cf. Verspohl 1975, 30.

69 Berghof 2010, 187.

70 Berghof upends Berkeley by critically remarking that both kinds of perception are of a tactile nature. Berghof 2010, 203: 'In formulating a theory of depth perception, what Berkeley does not acknowledge is that both kinds of sensation - internal feelings of the movement of optical nerves and external manual sensations are tactile'.

Descartes 2001, 104. Cited in Berghof 2010, 201.

Verspohl 1975, 29: 'Sehsinn und Tastsinn (...)

[konstituieren] im optischen oder taktilen

Bildwerk eine antithetische Einheit von

Weltvorstellung und Welterfahrung'.

73 Koss 2006, 142.

74 Koss 2006, 143. Fiedler, Helmholtz, and

Hildebrand address viewing from close-up and from a distance. Cf. Schawelka 1993, 401. Clausberg noted that Hildebrand nevertheless considered 'viewing from close-up, binocular stereoscopic observation, as impure and unsuitable for making artistic judgments'. Clausberg 2012, 6o. Translation Vischer 1994 (Das optische Formgefuhl, 1873). Imdahl 2003, 66.

For another perspective of the Paragone debate, see: Van Gastel et al. 2014; Hadjinicolaou 2018b. Carlo Ginzburg sees the notions of proximity and distance as ambivalent: they have more in common than they are disparate. While he does not definitely say that proximity and distance are opposites, he emphasizes that their contrariety arises from the fact that they refer to one another. See Ginzburg 1999, 252. Wolfram Pichler identifies the dialectic of the essential and the subsidiary with proximity and distance. Pichler 2007, 20.

78 Fehrenbach 2011, 142. On Plato and the image, see: Bredekamp 2010b, 36-43.

79 Fehrenbach 2011, 143; Krois 2011c, 265.

80 Aristotle: De Anima, II, 2,413b. Cf. Krois 2011c, 265; See Quiviger 2010, 105-120.

$81 \quad$ Binczek 2007, 5. Cf. Classen 2012.

82 Böhme 1998, 216.

83 Böhme 1998, 215: 'Was sich nicht spüren, tasten, greifen lässt, das ist bloßer ,Geist', Gespenst und Phantom'.

84 See Didi-Huberman 2001; Rath et al. 2013. For example Michael Yonan essentially says this in the paper he presented at CIHA 2012 in Nuremberg ('Die Herausforderung des Objekts' [The challenge of the object]). It was part of the section 'Questioning the Subject of Art History' on 'The Suppression of Materiality in AngloAmerican Art-Historical Writing'. Yonan 2013, 63-66. See Roodenburg 2014, 1-17.

85 Fehrenbach 2010a, 136. Cf. Ginzburg 2002, 7-57.

86 Schawelka 1993, 516: '(...) diese gespaltene Wahrnehmung von Ferne trotz körperlicher Nähe, von Kontemplation trotz emotionaler Steigerung [erlaubt] Experten von Laien zu scheiden'.

87 Didi-Huberman 1999b, 85 .

88 Elkins 2004, 17-19: 'From a distance a Rothko painting can be pleasing and even pretty. But if you walk up to it you may find yourself lost in a smear of colours. The paintings are like traps: harmless looking from a distance, disorienting 
or bewildering from nearby'. Elkins furthermore describes the physical involvement in the paintings Rothko executed for the chapel in Texas. In it he finds such an intimate relationship to the image that he would not even want to have with another person'.

The man's attitude calls to mind a drawing by Menzel in Berlin in which the artist examines in his painting of The flute concert, whether he is satisfied with his painting manner.

Ginzburg 1999, 7 .

Didi-Huberman 1999a, 167.

Warburg 2010, 586-587: 'Der bewusste besonnene Mensch steht zwischen Systole und Diastole. Greifen und Begreifen. Er bewegt sich gleichsam im Halbkreis von der Erde auf und zur Erde wieder hernieder. (...) Zwischen Greifen und Begreifen liegt die umreißende Umfangsbestimmung.

Cf. Treml et al. 2014.

Warburg 2010, 629-630. Cf. Verspohl 1975, 32: 'Zwischen imaginärem Zugreifen und begrifflicher Schau steht das hantierende Abtasten des Objekts mit darauf erfolgender plastischer oder malerischer Spiegelung, die man den künstlerischen Akt nennt'.

On the term intersensoriality, see: Howes 2005; Howes 2013, under: http://www.sensorystudies. org/sensorialinvestigations/the-expanding-fieldof-sensory-studies/ [24 Oct. 2013], Part III, A Full Complement of the Senses. thing similar in her book on Titian: 'The more obvious layering of paint, the exposure of the establish a spatial and temporal kinaesthetic relationship with the beholder that involves the body'. Cranston 2010, 15 .

Cf. Schneider/Zitzlsperger 2006, 83 .

Boehm \& Burioni 2012.

See the remarks on the active, acting, and
Cf. Summers 1987. Jodi Cranston describes somecanvas support, and the traces of the brushstroke intrinsic light in Chapter IV, 188-189. In Chefd'oeuvre inconnu Balzac tells a story similar to Chantelou's account of Bernini: “"The old lansquenet is laughing at us", Poussin said, moving once more toward the supposed picture. "I can see nothing there but confused masses of colour and a multitude of fantastical lines that go to make a dead wall of paint". (...) In a corner of the canvas, as they came nearer, they distinguished a bare foot emerging from the chaos of colour, half-tints and vague shadows that made up a dim, formless fog. Its living delicate beauty held them spellbound'. Balzac 2007 [EBook \#2306o]. Accessed 15 Feb. 2018] Balzac 2001, 168-169. It is the very proximity that leads to cognition, as the 'fine painter' Poussin realizes as he steps up closer to the painting and, despite the seeming formlessness, sees how, in this struggle of paints and colours, the tip of a naked foot emerges which he could not perceive from afar. This element leads Didi-Huberman to investigate why this detail in painting receives the attention it gets. He calls it the 'Pan' of painting. DidiHuberman 2007, 62-63 and 80-84. Balzac turns the clichés of amorphous proximity and the manifestation of form from a distance upside down and thereby underscores the absurdity of differentiating between the two. In the famous scene in Antonioni's movie Blow Up, the contemporary audience learns that moving closer to view an image (in this case a photograph) can bring new insights or evidence to light. The photographer, like a connoisseur (in the style of Berenson), examines his own photograph with a magnifying glass. In this way an inconspicuous detail, which only can be recognized from closeup and at first seems amorphous, helps solve a murder case. Cf. Reuter 2011, 191. The fact that the photography in Blow Up has become a metaphor in the science of images is evidenced in Belting 2007a. See Belting's article in the same volume (Belting 2007b, 59). Noë calls this bodily movement 'sensorimotor bodily skill'. Noë 2004, 11. Cf. Largier 2010, 121-122. This use of tactus in the broad sense was likewise developed in film studies. Cf. Barker 2009, 1: 'The hands then are only the beginning, the contact point, of a mutual engagement of body and mind that extends deep into the body, involving the muscles and tendons as surely as the fingers'.

102 Barker 2009, 17.

103 Cf. Bredekamp 2013, 34-36. A passage in Franz Joachim Verspohl is representative for the notion of active viewing: 'The assumption of a temporal distance between passive and active viewing, a "calmly viewing" angle and a "touching and active one", clashes with the fundamental purpose of the artwork as an "act", which could only be done adequate justice to by active viewing as the appropriate mode of perception'. Verspohl $1975,28$. 
104 Verspohl 1975, 30 and 36.

105 'Conti: Ha! Daß wir nicht unmittelbar mit den Augen malen! Auf dem langen Wege aus dem Auge durch den Arm in den Pinsel, wie viel geht da verloren! (...) Oder meinen Sie, Prinz, daß Raphael nicht das größte malerische Genie gewesen wäre, wenn er unglücklicherweise ohne Hände wäre geboren worden?' Quoted after Link-Heer 1986, 112.

106 For a valid criticism of ocularcentrism, see: Pallasmaa 2012, 21-23.

107 Boschini 1966, 302. Quoted after Sohm 1991, 154-155: 'Quando per questo mi son stà Bassan/ Procurete d'aver bona licencia/ D'inzegnochiarme con gran reverencia/ Su quel Altar, per tocar con le man/ Quei colpi, quele machie e quele bote (...)'. Cf. Chapter III, 131.

108 Böhme 1998, 215.

109 Susan Hurley describes in her famous article how perception and actio belong together (2013, 379-412).

$110 \quad$ Sohm 1991, 146.

111 Freedberg/Gallese, 202. The parlance here is not about painting, but was studied concretely in experiments with Macaques. Cf. Maravita \& Atsushi 2004, 81.

112 Cranston 2010, 16. Cf. Chapter II, 77.

113 Aretino 1540. Quoted after von Rosen 2000, 185: '(...) con le man vedi, e con gli occhi tu tocchi'. Leonardo claimed that seeing activated the entire body. See Fehrenbach 2011, 151 (Leonardo, Libro di Pittura (\$ 23)).

114 Martin Warnke points out that a painting requires its beholders to view it from close-up and from a distance - and also explains why: 'From a distance the beholder sees an "intact" and clearly animated grouping, "closed" as far as the draughtsmanship goes. However, from close-up the beholder perceives the liberal manner of how the paint has been applied, how the looseness of the brush allows everything to melt into one another and "disperse". (...) The painting is not consistent and instead depends on the motions of the beholder who is left to complete it. These motions must be learned and they have their history'. Warnke 1997a, 8: 'Aus der Ferne (...) sieht der Betrachter eine "unversehrte", zeichnerisch geschlossene, klar bewegte Gruppe, während aus der Nähe ein großzügiger Farbduktus, ein lockerer Pinsel alles verschwimmen und "verfallen" lässt. (...) Das
Bild ist nicht identisch, sondern abhängig von den Bewegungen, die der Betrachter vor ihm vollzieht. Diese Bewegungen mußten gelernt werden, und sie haben ihre Geschichte'. On the fusion between seeing and touching $\mathrm{cf}$. Pallasmaa 2012, 30-32.

115 Wagner 2008, 51.

116 Schawelka 1993, 401; Krüger 2008, 2.

117 Krüger 2008, 5.

118 Krüger 2008, 30. Despite his valuable insights, Matthias Krüger fails to consider the corporeal factor (which is crucial in this context). Additionally, there was the problem of the placement of the pictures and the preference for certain artists to the detriment of others. This brings to mind Gainsborough's strategy of hanging his paintings at eye level. Constable's paintings were also to be viewed at eye level so that they could be seen from close-up. Cf. Wagner 2008, 55 .

119 Confirming this assumption De Gelder's or Christopher Paudiss' paintings were relegated to museum depots or hung in obscure places above doors in exhibition galleries. For this reason, their real strength is lost on their beholders; that is, they do not get the opportunity of producing physical moods through the power of their paint. Rudolf Arnheim describes how the point of reference for human beings is a system of coordinates based on their own body. Cf. Schawelka 1993 .

120 Quoted after Didi-Huberman 1999a, 150-151: 'Weil ich mich nähern kann, gibt es fur mich Nähe und Ferne. Die dritte Dimension, die Raum-Tiefe, ist kein rein optisches Phänomen. Der Sehende ist ein bewegliches Wesen'.

\section{Epilogue}

Michelson 1926, 16: 'De Gelder, der nicht besonders vertreten ist, hatte Pech, machte ihn ganz zornig. (...) Aber ganz erstaunt und überrascht stand er vor der Salome des Fabritius, die er bis dahin auch aus keiner Reproduktion gekannt hatte, überrascht durch die Ähnlichkeit mit seiner eigenen Salome. Von diesem Bilde kam er überhaupt nicht mehr los, den ganzen Tag sprach er davon. Darüber wollte er schreiben'.

$2 \quad$ Quoted after Stückelberger 1996, 117. For individual artists, this was already pursued in scholarship, see for instance: Cat. Madrid 2014a. 
$3 \quad$ Febvre 1977, 49.

$4 \quad$ Loh 2007.

5 McKim-Smith 1988, 17. Concerning the case of Greco see Hadjinicolaou 2019.

6 Cat. Madrid 2014b.

$7 \quad$ See Hadjinicolaou 2017.

8 Cornelis 2016, 67-109. Max Ernst (with his frottage) was a keen admirer of the Dutch artist Hercules Seghers, who in turn was a crucial source of inspiration for Rembrandt. Seghers' technique can be compared to Alexander Cozens' blotting. The spontaneous quality of the blot fascinated the adherents of automatic painting or even, as in the case of Seghers, 'automatic' printmaking. Cornelis 2016, 84. Heinz Spielmann was the first to draw a comparison between Seghers and Ernst. He called the former a forerunner of surrealism, not because of the motives the artist used as in the case of Bosch, but because of his way he implemented the materials and experimented with his medium. Cf. Spielmann 1960, 3-19.

Busch 2007, 121-139; Maclagan 2014.

Krüger 2018, 138-145.

Lorini 2004, 236.

Feser 2004, 213.

It is hardly a coincidence that many of the macchia artists amply used pentimenti to correct and further articulate what they wanted to express on canvas without a drawing to guide them.

14 Rosand 1997, 24. See McKim-Smith 1988, 17. 